\title{
PAPER
}

\section{Chemotherapeutic response to cisplatin- like drugs in human breast cancer cells probed by vibrational microspectroscopy $\dagger$}

\author{
A. L. M. Batista de Carvalho, ${ }^{\star a}$ M. Pilling, ${ }^{\text {b }}$ P. Gardner, ${ }^{b}$ J. Doherty, ${ }^{\text {bc }}$ \\ G. Cinque, ${ }^{C}$ K. Wehbe, ${ }^{c}$ C. Kelley, ${ }^{C}$ L. A. E. Batista de Carvalho ${ }^{a}$ \\ and M. P. M. Marques ${ }^{\star a d}$
}

Received 30th October 2015, Accepted 11th January 2016

DOI: $10.1039 / \mathrm{c} 5 \mathrm{fd} 00148 \mathrm{j}$

Studies of drug-cell interactions in cancer model systems are essential in the preclinical stage of rational drug design, which relies on a thorough understanding of the mechanisms underlying cytotoxic activity and biological effects, at a molecular level. This study aimed at applying complementary vibrational spectroscopy methods to evaluate the cellular impact of two $\mathrm{Pt}(\Perp)$ and $\mathrm{Pd}(\Perp)$ dinuclear chelates with spermine $\left(\mathrm{Pt}_{2} \mathrm{Spm}\right.$ and $\mathrm{Pd}_{2} \mathrm{Spm}$ ), using cisplatin (cis- $\left.\mathrm{Pt}\left(\mathrm{NH}_{3}\right)_{2} \mathrm{Cl}_{2}\right)$ as a reference compound. Their effects on cellular metabolism were monitored in a human triple-negative metastatic breast cancer cell line (MDA-MB-231) by Raman and synchrotron-radiation infrared microspectroscopies, for different drug concentrations $(2-8 \mu \mathrm{M})$ at $48 \mathrm{~h}$ exposure. Multivariate data analysis was applied (unsupervised PCA), unveiling drug- and concentration-dependent effects: apart from discrimination between control and drugtreated cells, a clear separation was obtained for the different agents studied mononuclear vs. polynuclear, and Pt(॥) vs. Pd(॥). Spectral biomarkers of drug action were identified, as well as the cellular response to the chemotherapeutic insult. The main effect of the tested compounds was found to be on DNA, lipids and proteins, the $\mathrm{Pd}(॥)$ agent having a more significant impact on proteins while its $\mathrm{Pt}(॥)$ homologue affected the cellular lipid content at lower concentrations, which suggests the occurrence of distinct and unconventional pathways of cytotoxicity for these dinuclear polyamine complexes. Raman and FTIR microspectroscopies were confirmed as powerful non-invasive techniques to obtain unique spectral signatures of the biochemical impact and physiological reaction of cells to anticancer agents.

\footnotetext{
a“Química-Física Molecular”, Univ. Coimbra, 3004-535 Coimbra, Portugal.E-mail: pmc@ci.uc.pt; analmbc@ gmail.com

${ }^{b}$ Manchester Institute of Biotechnology, Univ. Manchester, Manchester, M1 7DN, UK

${ }^{c}$ Diamond Light Source, Harwell Science and Innovation Campus, Didcot, Oxfordshire OX11 ODE, UK

${ }^{d}$ Dep. Life Sciences, Univ. Coimbra, 3000-456 Coimbra, Portugal

$\dagger$ Electronic supplementary information (ESI) available: Raman, FTIR and INS spectra $\left(600-1800 \mathrm{~cm}^{-1}\right)$ of the complexes under study. See DOI: 10.1039/c5fd00148j
} 


\section{A Introduction}

Chemotherapy is one of the main approaches in the management of cancer (alongside radiotherapy and surgery) and aims at killing neoplastic cells with minimal damage to healthy tissue. Breast cancer is the second most common type of cancer worldwide and the most frequent among women, ${ }^{1}$ being the leading cause of female mortality. Particularly for the more aggressive triple negative invasive breast carcinoma (lacking the oestrogen, progesterone and human epidermal growth factor receptors (ER, PR and HER2)), the prognosis is still poor due to its heterogeneity and high metastatic capacity. ${ }^{2,3}$ Development of new anticancer agents and therapeutic strategies against this type of tumour is therefore of paramount importance, aiming at a higher efficacy regarding cell growth inhibition and decreased invasiveness, coupled to lower acquired resistance and deleterious side effects. ${ }^{4}$

Since Rosenberg's serendipitous discovery of cisplatin $\left(\text { cis- } \mathrm{Pt}\left(\mathrm{NH}_{3}\right)_{2} \mathrm{Cl}_{2}\right)^{5-7}$ and in spite of the high number of studies in this field, ${ }^{7-10}$ only three platinum-based compounds are currently approved worldwide as anticancer drugs for clinical use: cisplatin, carboplatin and oxaliplatin, that act through covalent binding to DNA forming predominantly intrastrand 1,2- and 1,3-crosslinks, which induce cell cycle arrest and apoptosis. However (apart from being administered intravenously) they are associated with severe side effects (e.g. nephrotoxicity, hepatotoxicity or myelosuppression) as well as acquired resistance, which strongly limit their application, particularly in single agent chemotherapy. In addition, they display a very low efficiency against metastatic cancers, which are those responsible for a higher mortality worldwide. For the last two decades, particular attention has been paid to polynuclear Pt(II) and Pd(II) chelates (comprising 2 or 3 metal centres) with flexible polyamine ligands, aiming at an increased activity and higher selectivity. ${ }^{\mathbf{1 1}}$ These display a higher cytotoxicity towards several types of cancer (e.g. oestrogen-independent (ER ${ }^{-}$) breast carcinoma) as compared to the classic Pt(II) agents, due to more severe and less repairable DNA damage upon formation of long-range interstrand drug-DNA adducts, not available to conventional drugs. ${ }^{12,13}$ However, their mechanism of action is not yet fully understood at the molecular level. Furthermore, their Pd(II) analogues have recently arisen as innovative and promising alternatives to $\mathrm{Pt}$ (II) compounds, ${ }^{9-11,14,15}$ particularly against metastatic breast cancer, ${ }^{16}$ namely when using strongly coordinating polydentate ligands such as polyamines, which minimise displacement by sulfhydryl groups from glutathione and other cellular thiols (responsible for drug inactivation and deleterious side effects). ${ }^{17}$ A careful design of palladium complexes may thus allow targeting strategies leading to different profiles of drug activity and to a lack of cross-resistance as compared with platinum-based agents. ${ }^{12}$

In the last few years, the authors have been involved in the study of polynuclear platinum and palladium-based complexes with polyamine ligands as promising anticancer agents towards several human cancer cells (e.g. metastatic breast carcinoma, castration-resistant prostate cancer and melanoma). A thorough knowledge of these compounds and of their interactions with their main pharmacological target (DNA), as well as with other biomolecules involved in the drug pharmacokinetics (e.g. glutathione) and pharmacodynamics, has been attained 
through vibrational spectroscopy (Raman, FTIR and Inelastic Neutron Scattering (INS) $)^{18-24}$ coupled to synchrotron-based Extended X-ray Absorption Fine Structure (EXAFS), ${ }^{23}$ as well as by NMR metabolomics ${ }^{22,25}$ and electrochemical techniques. ${ }^{26,27}$ In order to design such effective chemotherapeutic agents, it is essential not only to determine their effect on cellular growth, metabolism and function, but also to understand the mechanisms (at a molecular level) associated with this biological impact. This can be accomplished through in vitro experiments in cells, followed by ex vivo and in vivo studies, coupled to high resolution spectroscopic techniques. In the last decades, vibrational spectroscopy has arisen as a suitable and extremely accurate analytical tool for the characterisation of biological systems, as it provides detailed data on the investigated sample. Its high sensitivity, non-invasive nature and real-time molecular imaging capability, without the need for dyes or external probes, allows the attainment of extremely accurate biochemical information and images of cells and tissues, in both in vitro and in vivo/in situ conditions. The interplay between the vibrational profile and spectra-structure correlation yields quantitative and readily comprehensible data even for inhomogeneous biological samples. In particular, Raman confocal microspectroscopy of cell cultures constitutes a unique probing technique, yielding precise information on their functionality and metabolic profile under distinct conditions, namely as a response to chemotherapeutic agents. ${ }^{28,29}$ Additionally, coupling the complementary technique Fourier transform infrared (FTIR) microspectroscopy to the brilliance of synchrotron radiation (SR) sources leads to a massive increase in the quality of the results (relative to benchtop globar sources), yielding broadband spectra with subcellular resolution and unsurpassed signal-to-noise ratio. This constitutes an unmatched approach for routine chemical profiling of cells, allowing accurate examination of cellular environments and monitoring of drug bioavailability, biodistribution and target site accumulation after administration, as well as drug delivery across biological barriers and cellular response to treatment. ${ }^{30-32}$ Since cells are known to have specific vibrational spectroscopic signatures for different physiological conditions (regarding viability, cell cycle, apoptosis or stress), a correlation between a particular vibrational profile and a definite effect or mode of action should predictably be attained. ${ }^{33}$

The present study aimed at probing the cellular impact of two $\mathrm{Pt}(\mathrm{II})$ and $\mathrm{Pd}(\mathrm{II})$ dinuclear chelates with the biogenic polyamine spermine $(\mathrm{Spm}=$ $\left.\mathrm{H}_{2} \mathrm{~N}\left(\mathrm{CH}_{2}\right)_{3} \mathrm{NH}\left(\mathrm{CH}_{2}\right)_{4} \mathrm{NH}\left(\mathrm{CH}_{2}\right)_{3} \mathrm{NH}_{2}\right)$, synthesised and fully characterised by the authors ${ }^{18-24,34-36}-\mathrm{Pt}_{2} \mathrm{SpmCl}_{4}$ and $\mathrm{Pd}_{2} \mathrm{SpmCl}_{4}$ (hereafter denominated $\mathrm{Pt}_{2} \mathrm{Spm}$ and $\left.\mathrm{Pd}_{2} \mathrm{Spm}\right)$. Raman microspectroscopy and synchrotron-radiation infrared microspectroscopy (SR-IRMS) were applied to probe the effects of their interaction with the cellular components, on a human triple-negative breast cancer cell line, as compared to the well established anticancer drug cisplatin. This was achieved relying on the microRaman equipment from the Vibrational Spectroscopy Laboratory for Bioprobing of the Research Group QFM/University of Coimbra (Portugal) (VIBIMA/QFM-UC), ${ }^{37}$ as well as on the state-of-the-art fingerprint microprobe analysis, detection and imaging capabilities of B22 beamline from Diamond Light Source (DLS, UK) (MIRIAM - Multimode InfraRed Imaging and Microspectroscopy)..$^{\mathbf{3 , 3 9}}$

The data obtained within this work, coupled to conformational analysis of the metal complexes and cytological assays (for evaluation of growth-inhibition, 
cytotoxic and anti-metastatic activities) previously carried out at QFMUC, ${ }^{14-16,22,25-27,40-45}$ will pave the way for future studies on other platinum and palladium-based polyamine agents prepared by the authors. This approach should provide valuable clues for the rational design of novel cisplatin-like drugs, displaying a higher efficiency, lower toxicity, decreased acquired resistance and possible oral administration.

\section{B Methods}

\section{B.1 Chemicals}

Antibiotics (penicillin-streptomycin $100 \times$ solution), Dulbecco's Modified Eagle's Medium-high glucose (DMEM-HG, $4500 \mathrm{mg} \mathrm{L}^{-1}$ glucose), cis-dichlorodiammine platinum(II) (cisplatin, $\mathrm{Pt}\left(\mathrm{NH}_{3}\right)_{2} \mathrm{Cl}_{2},>98 \%$ ), ethylenediaminetetraacetic acid (EDTA, disodium salt, dihydrate), formalin (10\% neutral-buffered formalin, $c a$. $4 \%$ formaldehyde), phosphate buffered saline (PBS), potassium tetrachloropalladate(II) $\left(\mathrm{K}_{2} \mathrm{PdCl}_{4},>99.9 \%\right)$, potassium tetrachloroplatinate(II) $\left(\mathrm{K}_{2} \mathrm{PtCl}_{4}\right.$, $>99.9 \%)$, spermine ( $N, N^{\prime}$-bis(3-aminopropyl)-1,4-diaminobutane), trypan blue $(0.4 \%)$, trypsin-EDTA $(1 \times)$, and inorganic salts and acids (of analytical grade) were purchased from Sigma-Aldrich Chemical S.A. (Sintra, Portugal). Fetal bovine serum (FBS) was obtained from Gibco-Life Technologies (Porto, Portugal).

\section{B.2 Synthesis and characterisation of the complexes}

Synthesis of the $\mathrm{Pt}_{2} \mathrm{Spm}$ and $\mathrm{Pd}_{2} \mathrm{Spm}$ complexes were carried out according to published procedures, ${ }^{46}$ optimised by the authors. ${ }^{24,41}$ Briefly, 2 mmol of $\mathrm{K}_{2} \mathrm{PtCl}_{4}$ or $\mathrm{K}_{2} \mathrm{PdCl}_{4}$, respectively, was dissolved in a minimal amount of water, and an aqueous solution containing $1 \mathrm{mmol}$ of spermine was added dropwise under continuous stirring. The reaction was allowed to occur for $24 \mathrm{~h}$, after which the resulting yellow powder was filtered off and washed with acetone. Recrystallization of these products from water afforded yellow-orange needle-shaped crystals. The newly synthesised compounds were fully characterised (and tested as to their purity) by elemental analysis and vibrational spectroscopy ${ }^{\mathbf{1 8 2 4}}$ (FTIR, Raman and INS, coupled to $a b$ initio theoretical calculations, Fig. S1/ESI $\dagger$ ).

$\mathrm{Pt}_{2} \mathrm{Spm}$ (yield 60\%) - elemental analysis, found (for $\mathrm{Pt}_{2}\left(\mathrm{C}_{10} \mathrm{~N}_{4} \mathrm{H}_{26}\right) \mathrm{Cl}_{4}$ ): C: 16.2\%; H: 3.5\%; N: 7.6\%, Cl: 19.1\%; calculated - C: 16.4\%; H: 3.6\%; N: 7.5\%, Cl: 19.3\%. $\mathrm{Pd}_{2} \mathrm{Spm}$ (yield 68\%) - elemental analysis, found (for $\mathrm{Pd}_{2}\left(\mathrm{C}_{10} \mathrm{~N}_{4} \mathrm{H}_{26}\right) \mathrm{Cl}_{4}$ ): C: 21.2\%; H: 4.7\%; N: 9.6\%, Cl: 25.9\%; calculated - C: $21.5 \% ; \mathrm{H}: 4.7 \% ; \mathrm{N}: 9.9 \%, \mathrm{Cl}$ : $25.6 \%$.

The FTIR spectra of the solid complexes were obtained (at room temperature, in $\mathrm{KBr}$ disks $c a .0 .5 \%(\mathrm{w} / \mathrm{w})$ ) using a Bruker Optics Vertex 70 FTIR spectrometer, coupled to a $\mathrm{KBr}$ beamsplitter and a liquid nitrogen cooled Mercury Cadmium Telluride (MCT) detector. Each spectrum was the sum of 50 scans, at a $2 \mathrm{~cm}^{-1}$ resolution. The error in wavenumbers was estimated to be less than $1 \mathrm{~cm}^{-1}$. The Raman spectra of $\mathrm{Pt}_{2} \mathrm{Spm}$ and $\mathrm{Pd}_{2} \mathrm{Spm}$ were acquired (at room temperature) with a Bruker RFS-100 Fourier transform Raman spectrometer, equipped with an InGaAs detector, with near-infrared excitation (in order to overcome fluorescence) provided by the $1064 \mathrm{~nm}$ line of a Nd:YAG laser (Coherent, model Compass-1064/ $500 \mathrm{~N}$ ) yielding $c a .150 \mathrm{~mW}$ at the sample position. A $180^{\circ}$ geometry was employed, and each spectrum was the average of three repeated measurements of 50 scans 
each, the resolution being set to $2 \mathrm{~cm}^{-1}$. The neutron measurements were carried out at the ISIS Pulsed Neutron Source of the Rutherford Appleton Laboratory (UK). INS data were recorded (at $10 \mathrm{~K}$ ) on the TOSCA spectrometer, ${ }^{47,48}$ an indirect geometry time-of-flight, high resolution $((\Delta E / E) c a$. 1.25\%), broad range spectrometer.

\section{B.3 Preparation of solutions}

Stock solutions were prepared in PBS, at concentrations of $1 \mathrm{mM}$ for cisplatin, and $500 \mu \mathrm{M}$ for $\mathrm{Pt}_{2} \mathrm{Spm}$ and $\mathrm{Pd}_{2} \mathrm{Spm}$, sterile-filtered and stored at $-20{ }^{\circ} \mathrm{C}$. Further dilutions to the final desired concentrations were made in PBS, immediately before addition to the cells.

\section{B.4 Cell culture}

The epithelial human breast cancer cell line MDA-MB-231 (human Caucasian triple-negative, claudin-low, breast carcinoma $)^{49}$ was purchased from the European Collection of Cell Cultures (ECACC, UK). The cells were cultured as monolayers, at $37{ }^{\circ} \mathrm{C}$, in a humidified atmosphere of $5 \% \mathrm{CO}_{2}$. The cultures were maintained in a DMEM-HG medium supplemented with $10 \%(\mathrm{v} / \mathrm{v})$ heat-inactivated FBS, $1 \%(\mathrm{v} / \mathrm{v})$ penicillin $\left(100 \mathrm{U} \mathrm{mL}^{-1}\right) /$ streptomycin $\left(100 \mathrm{mg} \mathrm{mL}^{-1}\right)$ and sodium bicarbonate-20 $\mathrm{mM}$ (pH 7.4). Cells were subcultured at $80 \%$ confluence, using trypsin-EDTA ( $1 \times)$. Under these conditions, the duplication time was $26 \mathrm{~h}$. The cells were always in the logarithmic phase of growth when the tested agents were added.

\section{B.5 Sample preparation for spectroscopic analysis}

Upon harvesting by trypsinization, cells were centrifuged and the pellet was resuspended in culture medium and seeded, at a concentration of $3 \times 10^{4}$ cells per $\mathrm{cm}^{2}$, on optical substrates suitable for either Raman ${ }^{50}$ or FTIR data collection: ${ }^{51}$ respectively $\mathrm{MgF}_{2}(2 \times 20 \mathrm{~mm})$ and $\mathrm{CaF}_{2}$ (IR-grade, $\left.1 \times 13 \mathrm{~mm}\right)$ disks, previously cleaned with ethanol-70\%. Upon incubation for $24 \mathrm{~h}$ (allowing the cells to attach), cells were treated with different concentrations of each tested compound (2, 4 and $8 \mu \mathrm{M})$ and left to culture for a further $48 \mathrm{~h}$. The growth medium was then removed, cells were washed twice with $\mathrm{NaCl}-0.9 \%$, fixed in $4 \%$ formalin (diluted in $\mathrm{NaCl}-0.9 \%$ from the commercial $10 \%$ neutral-buffered formalin solution) for $10 \mathrm{~min}$ (ref. 51) and washed several times with pure water (to remove any residual salt). The disks were allowed to air-dry prior to spectroscopic analysis. Spectral collection was performed for the dry samples at B22/DLS, and within $\mathrm{NaCl}-0.9 \%(\mathrm{w} / \mathrm{v})$ solution at VIBIMA/QFM-UC.

All samples were prepared in triplicate, in a single experiment.

\section{B.6 Vibrational spectroscopy}

B.6.1 Raman microspectroscopy. Raman spectra of MDA-MB-231 fixed cells on $\mathrm{MgF}_{2}$ disks, both untreated and drug-treated, were recorded (at room temperature) at the VIBIMA laboratory of the University of Coimbra (Portugal) ${ }^{37}$ and at the peripheral laboratories of the B22 beamline from Diamond Light Source (UK). ${ }^{38,39}$ In all cases, samples of untreated cells were used as a control.

At VIBIMA/QFM-UC, the spectra were obtained in the $600-1800 \mathrm{~cm}^{-1}$ range, using a Horiba Jobin-Yvon T64000 spectrometer in direct configuration mode 
(focal distance $0.640 \mathrm{~m}$, aperture $f / 7.5$ ), equipped with a holographic grating of 1800 grooves per $\mathrm{mm}$. The entrance slit was set to $200 \mu \mathrm{m}$. Rayleigh elastic scattering was rejected by a Notch filter, which reduces its intensity by a factor of $10^{6}$. The detection system was a liquid nitrogen cooled non-intensified $1024 \times$ 256 pixels $\left(1^{\prime \prime}\right) \mathrm{CCD}$. The $514.5 \mathrm{~nm}$ line of an $\mathrm{Ar}^{+}$laser (Coherent, model Innova 300-05) was used as the excitation radiation, yielding $c a .10 \mathrm{~mW}$ at the sample position. All the spectra were recorded using an Olympus $60 \times$ water immersion objective (Olympus LUMPLFLN 60XW, NA 1.0, wd 2 mm). A $200 \mu \mathrm{m}$ confocal pinhole rejected signals from out-of-focus regions of the sample. Apart from the control (untreated cells), samples containing 2,4 and $8 \mu \mathrm{M}$ of the tested drugs (48 $\mathrm{h}$ exposure) were analysed. 30 to 40 spectra were collected per sample (in different cells), with 4 accumulations and $60 \mathrm{~s}$ of exposure, at $<1 \mathrm{~cm}^{-1}$ spectral resolution.

At B22/DLS, Raman data for samples of fixed cells exposed to drugs at 2, 4 and $8 \mu \mathrm{M}$ (48 h exposure) and the controls were acquired in the $600-1800 \mathrm{~cm}^{-1}$ and 2600-3600 $\mathrm{cm}^{-1}$ regions, using a Bruker Senterra dispersive Raman microspectrometer with a CCD detector $(1024 \times 265$ pixels $)$, using a $100 \times$ objective (Olympus BX, NA 0.9, Japan), a $50 \mu \mathrm{m}$ diameter confocal aperture and a $532 \mathrm{~nm}$ laser line providing $c a .25 \mathrm{~mW}$ at the sample. 150 to 200 spectra were collected per sample (from cytoplasm and the nucleus for each cell, Fig. 1), with $5 \mathrm{~s}$ of exposure and 6 co-added scans per chosen point, sampling approximately 75 to 100 cells per sample, at 9-18 $\mathrm{cm}^{-1}$ spectral resolution.

B.6.2 SR-IRMS. Synchrotron-radiation infrared microspectroscopy data of MDA-MB-231 fixed cells on $\mathrm{CaF}_{2}$ IR optical substrates, both untreated and drugtreated, were acquired (at room temperature) at the infrared beamline B22 (MIRIAM) from Diamond Light Source (UK). ${ }^{38,39}$

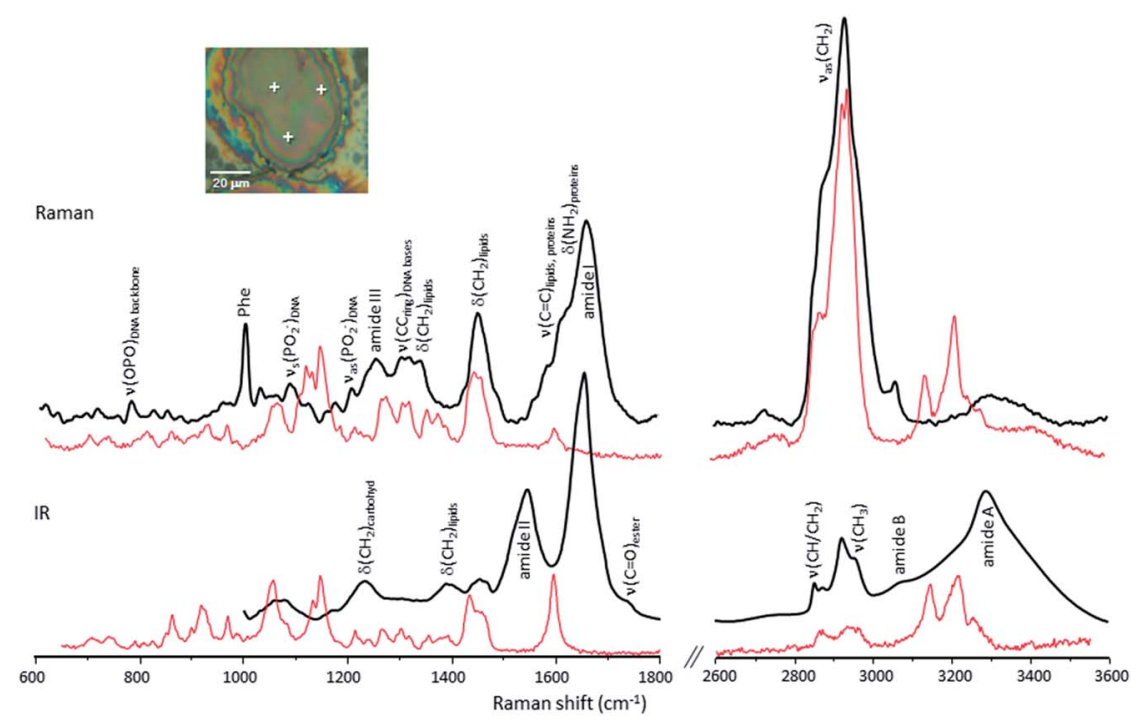

Fig. 1 Mean Raman (saline-dipped fixed cells, Horiba Jobin-Yvon T64000/514.5 nm) and infrared spectra (fixed cells, MIRIAM) for untreated MDA-MB-231 cells, and microscopic image of a cell $(\times 100$ magnification) showing some of the points at which data were captured. The spectra for $\mathrm{Pd}_{2} \mathrm{Spm}$ are shown in red. 
Acquisition in the mid-IR region $650-3900 \mathrm{~cm}^{-1}$ (Ge filter cut off) was carried out in transmission mode using a Hyperion 3000 microscope coupled to a Bruker Vertex 80 FTIR spectrometer, equipped with liquid nitrogen cooled Mercury Cadmium Telluride (MCT) high sensitivity detection $\left(50 \times 50 \mu \mathrm{m}^{2}\right.$ area) and a synchrotron radiation IR source yielding $300 \mathrm{~mA}$ at the sample position (microbeam fwhm ca. $15 \times 15 \mu^{2}$ and detected area between $5 \times 5$ to $15 \times 15$ $\mu \mathrm{m}^{2}$ selected via slits). An area of $10 \times 10 \mu \mathrm{m}^{2}$ at the sample (NA 0.5) matched with a $36 \times$ cassegrain condenser for transmission measurement.

Samples containing drug at 4 and $8 \mu \mathrm{M}$ concentrations (for a $48 \mathrm{~h}$ exposure) were analysed, as well as the controls (drug-free). 150 to 200 spectra were collected per sample (from at least 2 points per cell sampling 75 to 100 cells per sample, Fig. 1), with 256 co-added interferograms per chosen point (as well as background every 10 spectra), i.e. ca. $40 \mathrm{~s}$ per spectrum in order to obtain the signal-to-noise ratio for further data analysis. Three replicates were acquired for each sample.

\section{B.7 Data preprocessing and analysis}

Raman spectra collection was carried out using the LabSpec 5.0 (Horiba, France) and OPUS 7.2 (Bruker Optik, Germany) packages, respectively in VIBIMA/QFM-UC and B22/DLS. Data pre-processing was performed with The Unscramber ${ }^{\circledR} \mathrm{X}$ software version 10.2 (CAMO, Norway). Spurious peaks caused by cosmic rays were removed and the spectra were selected for data treatment by discarding those with a very poor $\mathrm{S} / \mathrm{N}$ ratio. The spectra were baseline corrected (second order polynomial in the $600-1800 \mathrm{~cm}^{-1}$ region and linear baseline correction for the 2650-3450 $\mathrm{cm}^{-1}$ interval), smoothed by the Savitsky-Golay filter (order 1, 9 points) which enabled the reduction of noise without band distortion, and vector normalised (minimising the effects of variable thickness within and among the cell samples).

FTIR data acquisition was performed using OPUS 7.2, which compensated for atmospheric and water vapour interferences, and corrected for background intensity changes within the chosen wavenumber interval. Infrared absorbance spectra were obtained by ratioing to a background measured from a clean area of the sample where no cells were present. Since for spectral acquisition in transmission mode the sample is illuminated through the substrate, reflection losses related to the relative refractive indices at the substrate-sample interface must be considered in the data treatment, as well as optical contributions from sample-air and air-substrate boundaries. This was achieved by RMieS correction (with the Extended Multiplicative Signal Correction (EMSC) algorithm, ${ }^{52,53} 20$ iterations) of the single cell spectra, vector normalised and mean centered. The spectra were corrected independently before computing the average spectrum per cell, as each spectrum may have experienced a different spectral distortion due to the heterogeneous nature of the cells distributed along the two-dimensional arrangement of pixels over which the sample was illuminated. The data were quality checked to remove any spectra which still exhibited high levels of scattering. Quality checking was based on the amide I band intensity, spectra with absorbance between 0.1 and 1 being retained. Initial pre-processing was based on a PC-based noise reduction algorithm: noise reduction was achieved by retaining a selected number of principal components and then recombing the dataset. Careful selection of the retained components enables random noise to be 
removed while still preserving the chemical information in the spectra. Utilising PC-based noise reduction of the data with 40 PCs enabled good improvements to be observed in the signal-to-noise ratio.

For both FTIR and Raman, the spectra were plotted using Origin 8.0 (OriginLab, USA). Multivariate analysis of the results - unsupervised principal components analysis (PCA) - was carried out with The Unscramber X 10.2 and using Matlab 2012a (The MathWorks Inc., Natick, MA) and the ProSpect Toolbox (London Spectroscopy Ltd., London, UK). The order of the PCs denotes their importance to the dataset, PC1 corresponding to the highest amount of variation. Analysis was carried out separately for each spectral region probed. For the Raman data, PCA was performed using the cross validation method, while for the infrared results the nonlinear iterative partial least squares algorithm and the leverage correction validation method were applied.

\section{Results and discussion}

Following previous biological studies by the authors on the effect of the tested $\mathrm{Pt}(\mathrm{II})$ and $\mathrm{Pd}$ (II) spermine complexes on the growth and viability of several human cancer cells, ${ }^{14-16,22,26,27,40,41,43,45}$ including the hormone-unresponsive breast carcinoma currently investigated, a cellular response at the biochemical level is presently sought, through analysis of the vibrational pattern of drug-treated and untreated cells. This multidisciplinary approach aims to link biological response to changes in cellular chemistry and metabolism, thus identifying the spectral markers of drug activity and paving the way for an understanding of the drug mode of action at the molecular level, hopefully helping to predict drug efficacy under specific conditions. According to former evaluation of the anti-tumour effect of $\mathrm{Pt}_{2} \mathrm{Spm}$ and $\mathrm{Pd}_{2} \mathrm{Spm}$ towards MDA-MB-231 cells, at different time-points and doses, ${ }^{16}$ a 2 to $8 \mu \mathrm{M}$ concentration range was chosen for the current study, for a drug-exposure period of $48 \mathrm{~h}$, as these conditions correspond to an optimal drug effect, the concentration leading to a $50 \%$ cell growth inhibition $\left(\mathrm{IC}_{50}\right)$ at $48 \mathrm{~h}$ being $5.4 \mu \mathrm{M}$ for $\mathrm{Pt}_{2} \mathrm{Spm}$ and $4.1 \mu \mathrm{M}$ for $\mathrm{Pd}_{2} \mathrm{Spm}$. Hence, since $\mathrm{IC}_{50}$ will induce cell growth inhibition in half the population of the probed cells, higher concentrations ( $\mathrm{ca}$. twice the $\mathrm{IC}_{50}$ value) were also tested in order to better identify the druginduced biochemical changes.

Spectral biochemical signatures of the cell, at each condition tested (type of drug and concentration), were generated by averaging the spectra acquired from different cellular locations. The data (both FTIR and Raman) were captured as single point spectra (Fig. 1), across a cell population comprising randomly distributed cells displaying a high spectral heterogeneity (also due to cells being in different points of the cell cycle). Therefore, a large number of data points is required, for the mean resulting spectrum to be representative of the sample. This procedure, as opposed to single cell spectral acquisition, minimizes the effect of the cell cycle profile (predominantly $\mathrm{G}_{1}$ under normal conditions). Cisplatin, a DNA major groove binder with a well characterised mechanism of action ${ }^{54}$ was used as a reliable control, its effect on the MDA-MB-231 cells being compared and correlated to that of the cisplatin-like dinuclear Pt(II) and Pd(II) chelates. Similarly to cisplatin, these are expected to be cell-cycle non specific agents, allowing their cellular impact to be accurately retrieved from analysis of the mean spectra currently recorded, which average out the possibly different chemical fingerprints 
from cells at different cell cycle stages within the probed population. The MDAMB-231 cell line showed to be sensitive to both tested spermine complexes, which induced clear spectral changes (complementary Raman and infrared) in the wide range presently analysed $\left(600-3600 \mathrm{~cm}^{-1}\right)$, enabling the identification of specific features (biomarkers) associated with the biochemical effect of each investigated agent and the subsequent physiological response from the cell - the spectral signature of drug action.

The cells were analysed upon chemical fixation with a $4 \%$ formaldehyde solution (formalin). This type of biocompatible preservation method is intended to retain the biochemical conditions as similar as possible to the native physiological state, for prolonged time periods, whilst minimising auto-fluorescence and avoiding contamination from the fixative. The effects of chemical fixation are known to be cell line- and fixative-dependent, but are still not fully characterised in the literature. Formalin is a widespread chemical fixative that causes crosslinking between the aldehyde and the primary and secondary amine groups of cellular proteins (via methylene bridges), creating a gel and thus retaining the cellular constituents in a close to in vivo relationship. While no considerable effects of this fixation procedure have been observed in the IR spectra of single cells, ${ }^{55}$ it is expected to induce some reduction in vibrational band intensity, resulting from the disruption of lipid assembly and from changes in protein conformation (mainly reflected in the amide I and II bands). Nevertheless, formalin fixation has been found to be the best method for preserving cellular integrity with a weak impact on the overall molecular content and yielding the spectral profile closest to that observed in the live state, while hardly affecting discrimination between cells under distinct conditions (namely control and drugexposed). ${ }^{31,56-58}$ No formalin contamination was verified in the measured spectral data, with no signals being detected for its typical $\mathrm{t}\left(\mathrm{CH}_{2}\right), \nu(\mathrm{CO})$ and $\delta\left(\mathrm{CH}_{2}\right)$ modes at ca. 907, 1040 and $1490 \mathrm{~cm}^{-1}$.

Despite the intense vibrational band characteristics of the tested Pt(II) and $\operatorname{Pd}(\mathrm{II})$ agents within the currently probed spectral window (Fig. 1 and S1/ESI $\dagger$ ), ${ }^{\mathbf{1 8 , 2 4}}$ they were indiscernible intracellularly (either by FTIR or Raman), which can be explained by the low concentrations used (not exceeding $8 \mu \mathrm{M}$ ), coupled to intracellular chloride hydrolysis and the strong interaction with their main pharmacological target (DNA) and other biomolecules. ${ }^{18,23,24}$ Also, the vibrational modes involving the metal center lie in the low frequency region of the spectrum (below $550 \mathrm{~cm}^{-1}$ ) which does not fall within the interval currently measured $(>600$ $\mathrm{cm}^{-1}$ ). It should be noted, however, that the $1000-1800 \mathrm{~cm}^{-1}$ interval may comprise features from the polyamine ligand within the dinuclear complexes, ${ }^{24}$ but these are overruled by the strong signals due to the cellular components (Table 1, Fig. 1).

Notwithstanding the complexity of the biochemical processes taking place within the cell, the use of chemometric techniques (PCA), providing further insight into the source of the observed spectral variability, enabled discrimination between spectral patterns obtained for distinct levels of drug exposure. From the loading plots corresponding to each principal component it was possible to derive biochemical information based on the differentiation between the tested conditions, and to evidence inter-group variance. Additionally, loading plots could be matched with the corresponding experimental spectra, and the positive and negative peaks in the loadings were assigned to the different groups observed 
Table 1 Raman and infrared bands for live human breast cancer cells (MDA-MB-231). Features from specific drug-prompted DNA and protein conformational rearrangements are presented in red. The signals exclusively detected by infrared are shaded in grey

\begin{tabular}{|c|c|c|c|c|}
\hline \multirow[t]{2}{*}{ Band $\left(\mathrm{cm}^{-1}\right)$} & \multicolumn{4}{|c|}{ Assignment $^{a}$} \\
\hline & Nucleic acids & Proteins & Lipids & Carbohydrates \\
\hline 622 & Z-DNA/dG $\left(\mathrm{v}(\mathrm{CC})_{\text {ring }}\right)$ & Phe $(\mathrm{t}(\mathrm{CC}))$ & & \\
\hline 645 & & $\mathrm{v}(\mathrm{CS}), \operatorname{Tyr}(\mathrm{t}(\mathrm{CC}))$ & & \\
\hline 668 & A-DNA/dG $\left(v(C C)_{\text {ring }}\right)$ & & & \\
\hline 669 & B-DNA/G,T (v(CC) ring $)$ & & & \\
\hline 678 & B-DNA/A,G,T,C (v(CC) ring $)$ & $\operatorname{Trp}\left(v(C C)_{\text {ring }}\right)$ & & \\
\hline $697-900$ & & & $\begin{array}{l}\text { phosphate esters } \\
\left(\mathrm{v}_{\mathrm{s}}(\mathrm{OPO})\right)\end{array}$ & \\
\hline 698 & B-DNA/dG $\left(v(C C)_{\text {ring }}\right)$ & Met (v(CS)) & & \\
\hline 717 & & & $\begin{array}{l}\text { phosphocholine } \\
\left(\mathrm{v}\left(\mathrm{C}-\left(\mathrm{CH}_{3}\right)_{3} \mathrm{~N}^{+}\right)\right.\end{array}$ & \\
\hline 728 & B-DNA/A (v(CC) ring $)$ & $\operatorname{Trp}\left(\mathrm{V}_{s}(\mathrm{CC})_{\mathrm{ring}}\right)$ & & \\
\hline 746 & B-DNA/T (v(CC) $\left.)_{\text {ring }}\right)$ & porphyrin $\left(\mathrm{v}(\mathrm{CC})_{\text {ring }}\right)$ & & \\
\hline 749 & Z-DNA (v(OPO) $\left.)_{\text {backbone }}\right)$ & & & \\
\hline 757 & B-DNA/dT (v(CC) ring $)$ & $\operatorname{Trp}\left(\mathrm{v}_{\mathrm{s}}(\mathrm{CC})_{\mathrm{ring}}\right)$ & & \\
\hline $782-795$ & $\mathrm{C}, \mathrm{T}, \mathrm{U}\left(\mathrm{v}(\mathrm{CC})_{\text {ring }}\right)$ & & & \\
\hline 785 & B-DNA (v(OPO) $\left.)_{\text {backbone }}\right)$ & & & \\
\hline 792 & Z-DNA (v(OPO) $\left.)_{\text {backbone }}\right)$ & & & \\
\hline 805 & A-DNA (v(OPO) backbone $)$ & & & \\
\hline 812 & RNA (v(OPO) backbone) & Pro, Tyr (v(CC)) & & \\
\hline 830 & B-DNA $\left(v(\mathrm{OPO})_{\text {backbone }}\right)$ & Pro, Tyr (v(CC)) & & \\
\hline $835-840$ & Z-DNA (v(OPO) $\left.)_{\text {backbone }}\right)$ & & & Glu $(\delta(C C O))$ \\
\hline 855 & & $\begin{array}{l}\text { Pro, Tyr, Val (v(CC), } \\
\delta(\mathrm{CCH}))\end{array}$ & & $\begin{array}{l}\text { polysaccharides } \\
(\mathrm{r}(\mathrm{COC}))\end{array}$ \\
\hline 868 & Z-DNA (v(OPO) backbone) & Pro $(v(C C))$ & & $\begin{array}{l}\text { mono, disaccharides } \\
(\mathrm{v}(\mathrm{COC}))\end{array}$ \\
\hline 879 & RNA (ribose, $v(C C)_{\text {ring }}$ ) & $\begin{array}{l}\operatorname{Tyr}\left(v(C C)_{\text {ring }}\right), \text { Hyp } \\
(v(C C))\end{array}$ & $\begin{array}{l}\text { phosphocholine } \\
\left(\mathrm{v}_{\mathrm{s}}\left(\mathrm{CCN}^{+}\right)\right)\end{array}$ & $v(C C), v(C-O)_{\text {ring }}$ \\
\hline 883 & & $\rho\left(\mathrm{CH}_{2}\right)$ & & \\
\hline 901 & deoxyribose $\left(\mathrm{v}(\mathrm{CC})_{\text {ring }}\right)$ & $v(C C)$ & fatty acids $(v(C C), v(C O))$ & $v(\mathrm{COC})$ \\
\hline 915 & RNA (ribose, $\mathrm{v}(\mathrm{CC})_{\text {ring }}$ ) & & & \\
\hline $920-940$ & $\begin{array}{l}\text { B-DNA/deoxyribose } \\
\left(\mathrm{v}(\mathrm{CC})_{\text {ring }}\right)\end{array}$ & Pro $(v(C C))$ & & Glu $(v(C C))$ \\
\hline $925-930$ & Z-DNA (v(OPO) backbone $)$ & & & \\
\hline $935-940$ & & $v(\mathrm{CC})(\alpha$-helix) & glycolipids $(\mathrm{v}(\mathrm{COC}))$ & $v(\mathrm{COC})_{\text {Elycosidic }}$ \\
\hline 940 & RNA/ribose $\left(\mathrm{v}(\mathrm{CC})_{\text {ring }}\right)$ & & & $\begin{array}{l}\text { polysaccharides (skeletal } \\
\text { modes) }\end{array}$ \\
\hline $950-1250$ & & $\begin{array}{l}\text { phosphorylated proteins } \\
\text { (v(OPO)) }\end{array}$ & & \\
\hline 951 & & $\mathrm{v}_{\mathrm{s}}\left(\mathrm{CH}_{3}\right)(\alpha$-helix $)$ & & \\
\hline $965-973$ & DNA $\left(v(C C) / v(C O)_{\text {backbone }}\right)$ & & & $\begin{array}{l}\text { polysaccharides } \\
(\delta(C=0))\end{array}$ \\
\hline 974 & RNA (ribose, v(CC) & & & \\
\hline 980 & & $v(\mathrm{CC})(\beta$-sheet $)$ & $\delta(\mathrm{C}=\mathrm{CH})$ & \\
\hline 1003 & & Phe $\left(v_{s}(C C)_{\text {ring }}\right)$ & & \\
\hline 1032 & & Phe $(\delta(\mathrm{CH})), \mathrm{v}\left(\mathrm{O}-\mathrm{CH}_{3}\right)$ & $\begin{array}{l}\text { v(CC), phospholipids } \\
(\delta(\mathrm{CH}))\end{array}$ & $v(\mathrm{CC}), v(\mathrm{CO}), \mathrm{v}(\mathrm{C}-\mathrm{OH})$ \\
\hline 1050 & RNA (v(OPO)) & & $\begin{array}{l}\text { phosphate esters } \\
\left(\mathrm{v}_{\mathrm{as}}(\mathrm{OPO})\right)\end{array}$ & $v(\mathrm{C}-\mathrm{OH})$ \\
\hline 1063 & $\begin{array}{l}\text { B-DNA/deoxyribose } \\
(\mathrm{v}(\mathrm{CO}))\end{array}$ & $v(C C), v(C N)$ & $v(\mathrm{CC}), \mathrm{v}(\mathrm{CO})$ & $v(\mathrm{CC}), v(\mathrm{CO}), \delta(\mathrm{OCH})$ \\
\hline 1082 & & $v(\mathrm{CC}), v(\mathrm{CN})$ & phospholipids $\left(\mathrm{v}_{\mathrm{s}}\left(\mathrm{PO}_{2}{ }^{2}\right)\right)$ & glycogen $(\mathrm{v}(\mathrm{CC}), \mathrm{v}(\mathrm{CO}))$ \\
\hline 1092 & B-DNA $\left(\mathrm{v}_{5}\left(\mathrm{PO}_{2}{ }^{\circ}\right)\right)$ & & & \\
\hline 1095 & $\mathrm{Z}$-DNA $\left(\mathrm{v}_{5}\left(\mathrm{PO}_{2}\right)\right)$ & & $v(\mathrm{CC}), v(\mathrm{CN})$ & $v(\mathrm{CC}), v(\mathrm{CO})$ \\
\hline 1099 & A-DNA $\left(\mathrm{v}_{\mathrm{s}}\left(\mathrm{PO}_{2}{ }^{-}\right)\right)$ & & & \\
\hline 1127 & RNA/ribose $(\mathrm{v}(\mathrm{CO}))$ & $v(\mathrm{CN})$ & $\begin{array}{l}v(C C)_{\text {acy }} \text { (trans } \\
\text { conformation) }\end{array}$ & $v(\mathrm{CO}), \mathrm{v}(\mathrm{CC})$ \\
\hline 1157 & & $v(\mathrm{CC}), v(\mathrm{CN}), \delta\left(\mathrm{CH}_{2}\right)$ & $\delta\left(\mathrm{CH}_{2}\right), \mathrm{v}(=\mathrm{C}-\mathrm{C}=)_{\text {conjugated }}$ & $\delta\left(\mathrm{CH}_{2}\right)$ \\
\hline 1158 & & $v(\mathrm{CC}), v(\mathrm{CO}), v(\mathrm{CN})$ & $\begin{array}{l}\text { phosphocholine } \\
\left(\mathrm{V}_{\mathrm{s}}\left(\mathrm{N}_{(}\left(\mathrm{CH}_{3}\right)_{3}{ }^{+}\right)\right.\end{array}$ & $v(\mathrm{CO})$ \\
\hline 1175 & $C, G, T\left(v(C C)_{\text {rine }}\right)$ & Tyr, Phe $(\delta(\mathrm{CH}))$ & & \\
\hline 1207 & & Hyp, Phe, Tyr (v(CC)) & & \\
\hline $1220-1300$ & & amide III $(\delta(\mathrm{NH}), \mathrm{v}(\mathrm{CN}))$ & & \\
\hline $1229-1235$ & & amide III/ $/$-sheet & & \\
\hline 1237 & B-DNA $\left(v_{a s}\left(\mathrm{PO}_{2}{ }^{-}\right)\right)$ & & & \\
\hline 1240 & $\operatorname{RNA}\left(\mathrm{v}^{(}\left(\mathrm{PO}_{2}{ }^{-}\right)\right)$ & & & \\
\hline $1243-1259$ & & amide III/random coil & & \\
\hline $1242-1266$ & RNA/dT (v(CC) ring) & & & \\
\hline $1247-1252$ & $\mathrm{C}\left(\delta\left(\mathrm{NH}_{2}\right)\right)$ & & & \\
\hline $1252-1264$ & $A, T\left(v(C C)_{\text {ring }}\right)$ & $\delta\left(\mathrm{CH}_{2}\right), \delta(\mathrm{C}=\mathrm{C}-\mathrm{H})$ & $\begin{array}{l}\delta\left(\mathrm{CH}_{2}\right) \\
\delta(\mathrm{C}=\mathrm{C}-\mathrm{H})_{\text {phospholipids }}\end{array}$ & $\delta\left(\mathrm{CH}_{2}\right), \omega\left(\mathrm{CH}_{2}\right), \mathrm{t}\left(\mathrm{CH}_{2}\right)$ \\
\hline 1254 & $\mathrm{dC}\left(\mathrm{v}(\mathrm{CC})_{\text {ring }}\right)$ & & & \\
\hline 1270 & $\mathrm{RNA} / \mathrm{C}, \mathrm{U}\left(\mathrm{V}(\mathrm{CC})_{\text {ring }}\right)$ & & phospholipds $(\delta(C=C))$ & \\
\hline
\end{tabular}




\begin{tabular}{|c|c|c|c|c|}
\hline 1272 & & amide III/ $\alpha$-helix & $\delta\left(\mathrm{CH}_{2}\right), \omega\left(\mathrm{CH}_{2}\right), \mathrm{t}\left(\mathrm{CH}_{2}\right)$ & $\delta\left(\mathrm{CH}_{2}\right), \omega\left(\mathrm{CH}_{2}\right), \mathrm{t}\left(\mathrm{CH}_{2}\right)$ \\
\hline 1300 & RNA/A,C ( $\left.(C C)_{\text {ring }}\right)$ & & & \\
\hline 1318 & $\mathrm{G}\left(\mathrm{v}(\mathrm{CC})_{\text {ring }}\right)$ & $\delta\left(\mathrm{CH}_{2}\right)$ & $\delta\left(\mathrm{CH}_{2}\right)$ & $\delta\left(\mathrm{CH}_{2}\right)$ \\
\hline 1323 & $\mathrm{G}\left(\mathrm{v}(\mathrm{CC})_{\text {ring }}\right)$ & & & \\
\hline 1339 & $\mathrm{G}\left(\mathrm{v}(\mathrm{CC})_{\text {ring }}\right)$ & & & \\
\hline 1340 & $A, G\left(V(C C)_{\text {ring }}\right)$ & $\delta\left(\mathrm{CH}_{2}\right), \operatorname{Trp}\left(\mathrm{v}(\mathrm{CC})_{\text {ring }}\right)$ & & $\delta\left(\mathrm{CH}_{2}\right)$ \\
\hline 1375 & $A, G, T\left(v(C C)_{\text {ring }}\right)$ & glycoproteins $\left(\delta\left(\mathrm{CH}_{3}\right)\right)$ & $\begin{array}{l}\text { lipids/acyl chains } \\
\left(\delta\left(\mathrm{CH}_{3}\right)\right)\end{array}$ & saccharides $\left(\delta\left(\mathrm{CH}_{2}\right)\right)$ \\
\hline 1396 & & $\delta\left(\mathrm{CH}_{2}\right), \rho\left(\mathrm{CH}_{2}\right)$ & $\begin{array}{l}\text { membrane lipids } \\
\left(\delta\left(\mathrm{CH}_{2}\right)\right)\end{array}$ & $\delta\left(\mathrm{CH}_{2}\right), \rho\left(\mathrm{CH}_{2}\right)$ \\
\hline 1405 & & $\delta\left(\mathrm{NH}_{2}\right)$ & & \\
\hline 1420 & A-DNA $\left(\delta\left(\mathrm{CH}_{2}\right)\right)$ & & & \\
\hline $1420-1480$ & & $\delta\left(\mathrm{CH}_{2}\right), \delta\left(\mathrm{CH}_{3}\right)$ & $\begin{array}{l}\delta\left(\mathrm{CH}_{2}\right), \delta\left(\mathrm{CH}_{3}\right) \text {, aromatic } \\
\text { lipids }\end{array}$ & $\delta\left(\mathrm{CH}_{2}\right)$ \\
\hline 1421 & $A, G\left(v(C C)_{\text {ring }}\right)$ & & & \\
\hline 1423 & B-DNA/A,G $\left(\delta\left(\mathrm{CH}_{2}\right)\right)$ & & & \\
\hline 1425 & Z-DNA $\left(\delta\left(\mathrm{CH}_{2}\right)\right)$ & & & \\
\hline $1440-1450$ & & & $\delta\left(\mathrm{CH}_{2}\right)$ & \\
\hline 1483 & & $\delta\left(\mathrm{NH}_{3}\right)$ & & \\
\hline 1487 & $\mathrm{~A}, \mathrm{G}\left(\mathrm{v}(\mathrm{CC})_{\text {ring }}\right)$ & $\delta\left(\mathrm{NH}_{3}{ }^{+}\right)$ & & \\
\hline 1512 & & $\operatorname{Tyr}\left(v(C C)_{\text {ring }}\right)$ & & \\
\hline 1513 & $\mathrm{C}\left(\mathrm{v}(\mathrm{CC})_{\text {ring }}\right)$ & & & \\
\hline 1518 & & $\mathrm{v}(\mathrm{C}=\mathrm{C})_{\text {porphyrin }}$ & & \\
\hline $1550-1560$ & & $\begin{array}{l}\text { amide II } \\
((\delta(\mathrm{CN}-\mathrm{H}) / \mathrm{v}(\mathrm{CN}))\end{array}$ & & \\
\hline 1555 & $\mathrm{G}\left(\mathrm{v}(\mathrm{CC})_{\text {ring }}\right)$ & $\begin{array}{l}\operatorname{Trp}\left(v(C C)_{\text {ring }}\right) \\
v(C=C)_{\text {porphyrin }}\end{array}$ & & \\
\hline 1579 & $\mathrm{~A}, \mathrm{G}\left(\mathrm{v}(\mathrm{CC})_{\text {ring }}\right)$ & & & \\
\hline 1582 & & $v(C=C), v(C=N)$ & $v(C=C), v(C=N)$ & \\
\hline 1604 & $\mathrm{~T}\left(\mathrm{v}(\mathrm{CC})_{\text {ring }}\right)$ & Phe $(\delta(\mathrm{C}=\mathrm{CH}))$ & & \\
\hline $1604-1618$ & $\mathrm{~A}\left(\mathrm{v}(\mathrm{CC})_{\text {ring }}\right), \mathrm{C}\left(\delta\left(\mathrm{NH}_{2}\right)\right)$ & $\begin{array}{l}\text { Phe, Tyr, Trp }(v(\mathrm{C}=\mathrm{C})) \\
\delta\left(\mathrm{NH}_{2}\right)\end{array}$ & & \\
\hline 1660 & DNA $(\delta(\mathrm{NH}))$ & Amide I $(v(C=0)) / \alpha$-helix & $v(C=C)$ & \\
\hline $1612-1690$ & & $\begin{array}{l}\text { amide I/ } \beta \text {-sheet, } \\
\text { antiparallel }\end{array}$ & & \\
\hline $1626-1640$ & & amide $\mathrm{I} / \beta$-sheet, parallel & & \\
\hline $1640-1650$ & & amide $\mathrm{I} /$ random coil & & \\
\hline 1690 & & $\mathrm{v}(\mathrm{C}=\mathrm{O})_{\text {amino acid side chain }}$ & & \\
\hline 1712 & A-DNA $(v(C=0))$ & & & \\
\hline 1717 & B-DNA $(v(C=0))$ & & & \\
\hline $1730-1742$ & & & $\begin{array}{l}\text { phospholipids } \\
\left(\mathrm{v}(\mathrm{C}=\mathrm{O})_{\text {ester }}\right)\end{array}$ & \\
\hline $2850-2875$ & & $\mathrm{~V}_{\mathrm{s}}\left(\mathrm{CH}_{2}\right)$ & $\mathrm{V}_{\mathrm{s}}(\mathrm{CH}), \mathrm{v}_{\mathrm{s}}\left(\mathrm{CH}_{2}\right)$ & $\mathrm{v}_{\mathrm{s}}(\mathrm{CH}), \mathrm{v}_{\mathrm{s}}\left(\mathrm{CH}_{2}\right)$ \\
\hline 2880 & & $\mathrm{~V}_{5}\left(\mathrm{CH}_{3}\right)$ & $\mathrm{V}_{\mathrm{s}}\left(\mathrm{CH}_{3}\right)$ & $\mathrm{V}_{\mathrm{s}}\left(\mathrm{CH}_{3}\right)$ \\
\hline 2900-2935 & & $\mathrm{V}_{\mathrm{as}}\left(\mathrm{CH}_{2}\right)$ & $\mathrm{V}_{\mathrm{as}}\left(\mathrm{CH}_{2}\right)$ & $\mathrm{V}_{\mathrm{as}}\left(\mathrm{CH}_{2}\right)$ \\
\hline 2960 & & $\mathrm{~V}_{\mathrm{as}}\left(\mathrm{CH}_{3}\right)$ & $\mathrm{V}_{\mathrm{as}}\left(\mathrm{CH}_{3}\right)$ & $\mathrm{V}_{\mathrm{as}}\left(\mathrm{CH}_{3}\right)$ \\
\hline 3060 & & amide $\mathrm{B}$ & & \\
\hline $3250-3290$ & & amide $\mathrm{A}(\mathrm{v}(\mathrm{NH}))$ & & \\
\hline $3300-3350$ & & & $\mathrm{v}(\mathrm{OH})$ & $\mathrm{v}(\mathrm{OH})$ \\
\hline
\end{tabular}

${ }^{a}$ A - adenine; C - cytosine; dG - deoxyguanine; dT - deoxythymine; G - guanine; Glu glucose; Hyp - hydroxyproline; Met - methionine; Phe - phenylalanine; Pro - proline; T thymine; Trp - tryptophan; Tyr - tyrosine; U - uracil; Val - valine. $\delta$ - in-plane deformation; $\Upsilon \mathrm{Y}$ - out-of-plane deformation; $v$ - stretching; $\rho$ - rocking; $\mathrm{t}$ - twisting; $\omega$ wagging. s - symmetric; as - anti-symmetric.

in the score plots. As discrimination was attained according to PCs dominated by spectral feature characteristics of the cellular components (and not the drugs), it may be concluded that the detected spectral variance is not due to the presence of the external agents but instead to their distinct effects on the cell's biochemical profile coupled to specific physiological reactions - the impact of the drugs is therefore being monitored.

\section{C.1 Raman microspectroscopy}

The Raman spectra of the MDA-MB-231 fixed cells, prior to drug administration (Fig. 1), reflected a vibrational pattern consistent with a healthy state as opposed to dead cells, ${ }^{28,59}$ mainly evidenced by the DNA $\nu(\mathrm{O}-\mathrm{P}-\mathrm{O})_{\text {backbone }}$ and $\nu\left(\mathrm{PO}_{2}{ }^{-}\right)$ modes (respectively at 785 , and $1092 / 1237 \mathrm{~cm}^{-1}$ ), the $\nu(\mathrm{O}-\mathrm{P}-\mathrm{O})$ features assigned 
to phosphorylated proteins (from 950 to $1250 \mathrm{~cm}^{-1}$ ) and the protein amide I band $\left(\nu(\mathrm{C}=\mathrm{O})\right.$ at $\left.1660 \mathrm{~cm}^{-1}\right)$. The DNA $\nu(\mathrm{O}-\mathrm{P}-\mathrm{O})_{\text {backbone }}$ is the most sensitive peak to recognise cell death, since this is accompanied by a breakdown of the phosphodiester bonds in the double helix, leading to a significant reduction (up to 80\%) of the band intensity. The main Raman signals observed for untreated MDA-MB-231 cells are encompassed in Table 1. Assignment of the signals relied on reported studies on several cell lines and biomolecules. ${ }^{28,60,61}$ Two different visible lasers were used for the acquisition of the Raman spectra, with 514 and $532 \mathrm{~nm}$ wavelengths (at QFM-UC and DLS, respectively). This very small energy difference in the incident radiation did not lead to significant changes in the intensity of the observed bands (the efficiency of the Raman scattering process depending on the fourth power of the excitation frequency). Moreover, data collection either in dry samples or saline-dipped cells did not elicit any significant variations in the spectral profile (data not shown).

The spectra of drug-exposed cells after $48 \mathrm{~h}$ of incubation with cisplatin and the Pt- and Pd-spermine agents displayed marked differences relative to the nonexposed (control) cells, reflected in vibrational features associated with specific biomolecules. Additionally, a slight blue shift (ca. 2-3 $\mathrm{cm}^{-1}$ ) was detected for some features assigned to proteins $\left(\nu(\mathrm{CN})\right.$, amide I) and lipids $\left(\delta\left(\mathrm{CH}_{2} / \mathrm{CH}_{3}\right)\right)$, in agreement with previously reported studies. ${ }^{62,63}$ Upon unsupervised PCA analysis, a more detailed picture of the drug-impact on the cellular biochemical profile was

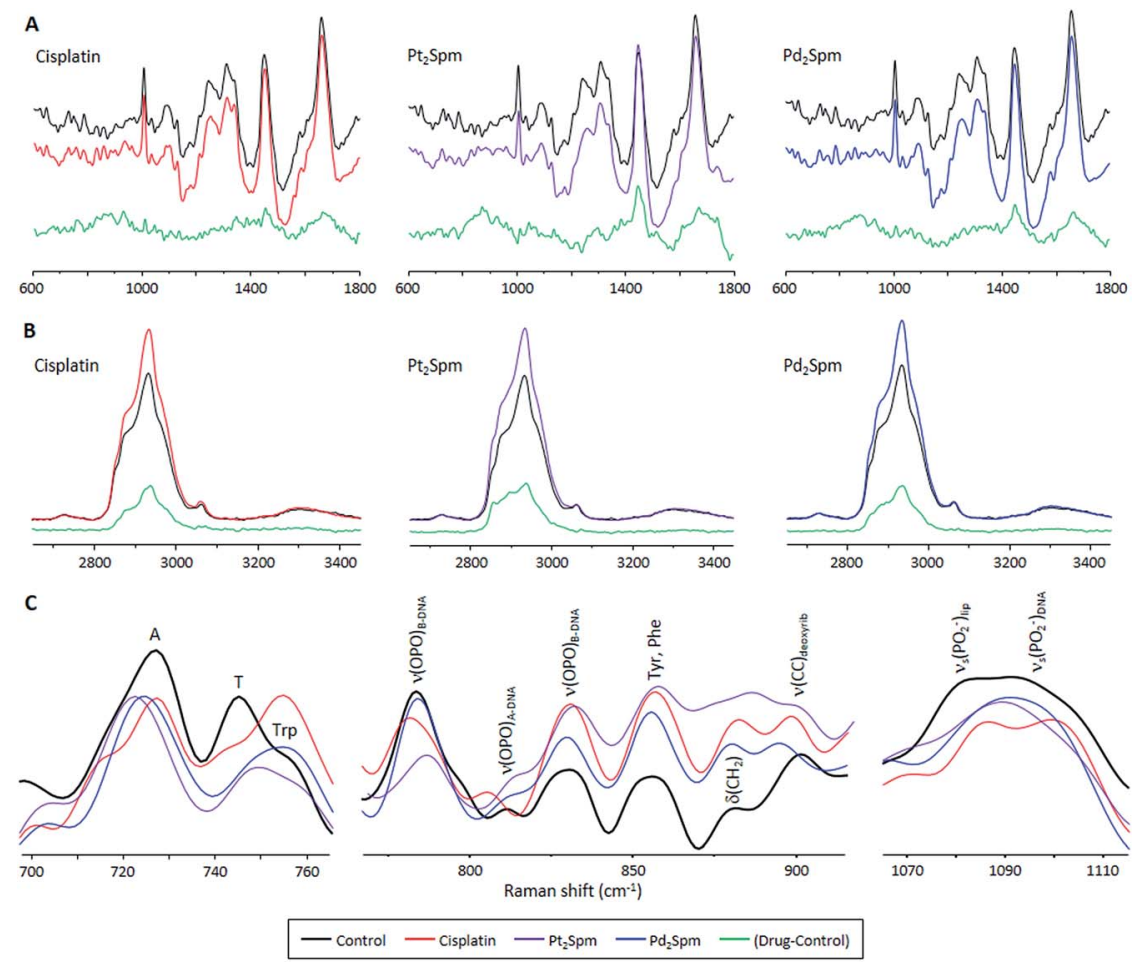

Fig. 2 Mean Raman spectra (fixed cells, Bruker Senterra/532 nm, 600-1800 cm ${ }^{-1}$ (A) and $\left.2650-3450 \mathrm{~cm}^{-1}(B)\right)$, and difference spectra to the control, for drug-treated (4 $\left.\mu M\right)$ MDAMB-231 cells. (C) - Particular spectral regions affected by drug exposure. 
attained. A drug-dependent response was verified, as depicted in Fig. 2, which represents the mean Raman spectra measured for cells upon incubation with cisplatin, $\mathrm{Pt}_{2} \mathrm{Spm}$ and $\mathrm{Pd}_{2} \mathrm{Spm}$, at $4 \mu \mathrm{M}$, and the difference spectra to the control, the corresponding PCA loading and score plots being shown in Fig. 3.

The most affected DNA bands upon drug exposure were found to be those from deoxyguanine (dG, $698 \mathrm{~cm}^{-1}$ ), thymine $\left(746,782,1375,1604 \mathrm{~cm}^{-1}\right)$, adenine (728, 1252, 1340-1487, 1579, 1604-1618 $\left.\mathrm{cm}^{-1}\right)$, cytosine $\left(782-795 \mathrm{~cm}^{-1}\right)$, guanine
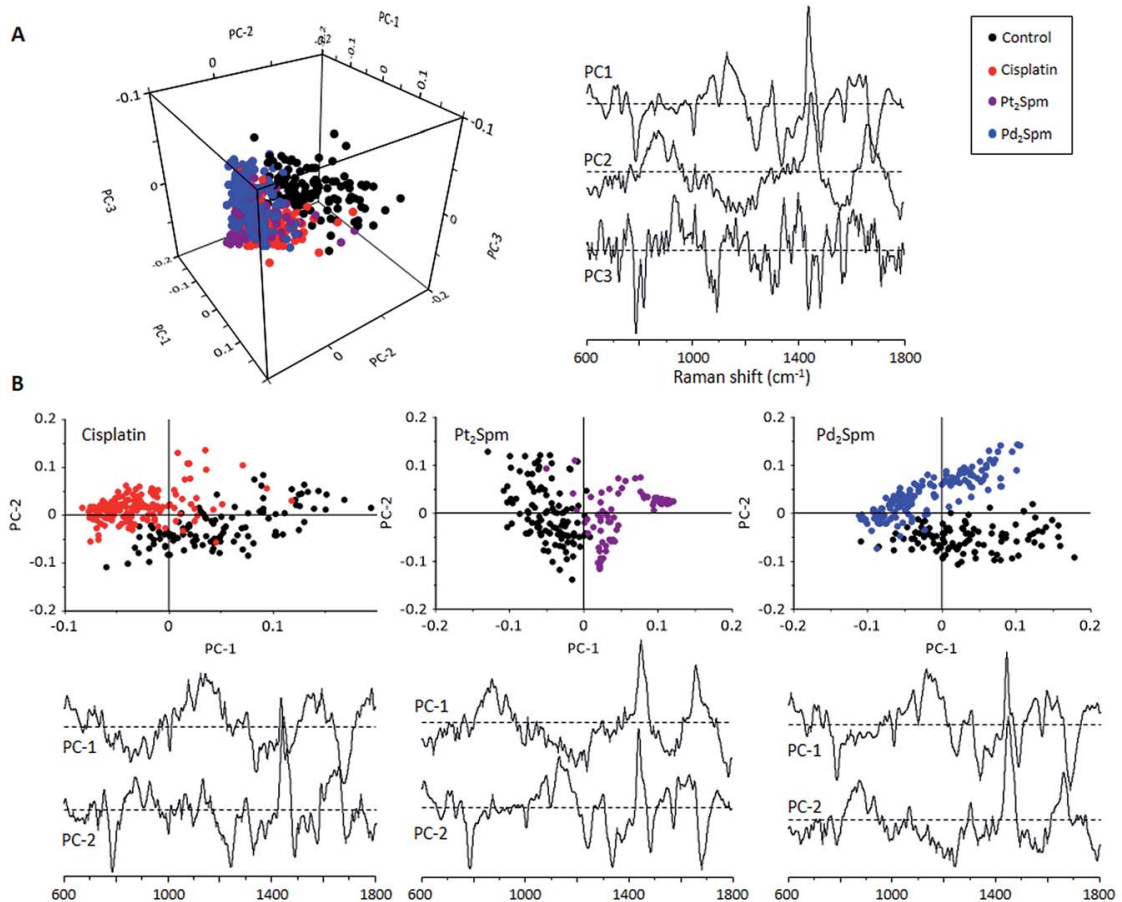

C
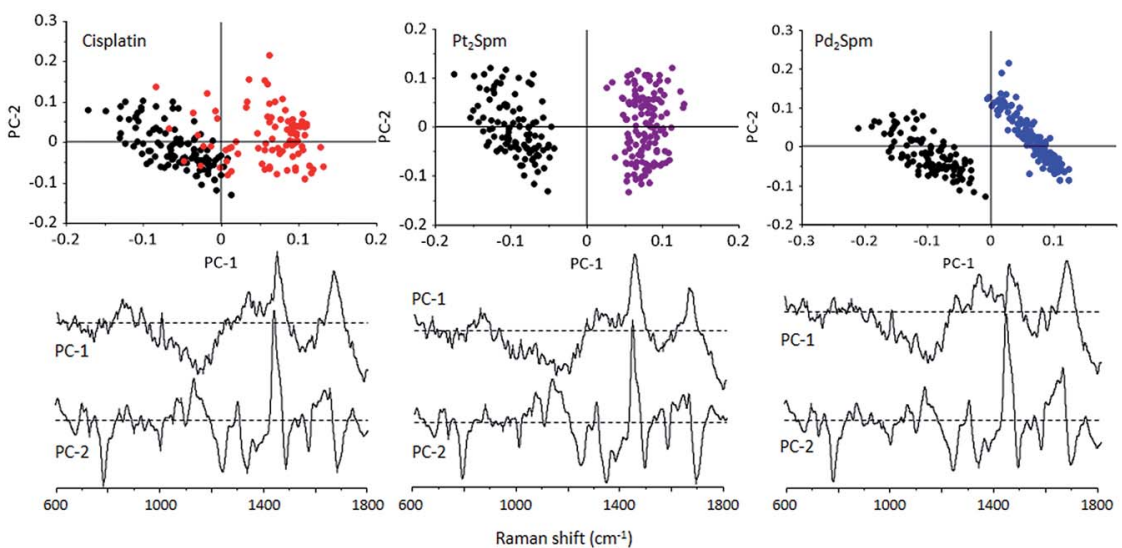

Fig. 3 PCA score and loading plots of Raman data (fixed cells, Bruker Senterra/532 nm, $600-1800 \mathrm{~cm}^{-1}$ ) for drug-treated MDA-MB-231 cells versus the control: all tested agents, $4 \mu \mathrm{M}$ (A). Cisplatin, $\mathrm{Pt}_{2} \mathrm{Spm}$ and $\mathrm{Pd}_{2} \mathrm{Spm}-4 \mu \mathrm{M}$ (B) and $8 \mu \mathrm{M}$ (C) (for clarity the loadings are offset, the dashed horizontal lines indicating zero loading). 
(669-678, 1175, 1318-1375, 1421-1487, 1555-1579 $\mathrm{cm}^{-1}$ ) and deoxyribose (901$940,1063 \mathrm{~cm}^{-1}$, more perturbed by the polynuclear agents than by cisplatin) (Table 1). These variations evidence the occurrence of drug-DNA crosslinks, predominantly intrastrand 1,2 GG, 1,2 AG, 1,3 GTG, ${ }^{64}$ leading to local unwinding of the native helix. While the adenine ring breathing vibration at $728 \mathrm{~cm}^{-1}$ decreased in intensity and was slightly red-shifted upon treatment with $\mathrm{Pt}_{2} \mathrm{Spm}$ and $\mathrm{Pd}_{2} \mathrm{Spm}$ (to 723 and $725 \mathrm{~cm}^{-1}$, respectively), the thymine band at $746 \mathrm{~cm}^{-1}$ was deviated to higher frequencies in the presence of cisplatin or $\mathrm{Pt}_{2} \mathrm{Spm}(755$ $\mathrm{cm}^{-1}$ ) and $\operatorname{Pd}_{2} \mathrm{Spm}\left(749 \mathrm{~cm}^{-1}\right.$ ) (Fig. 2(C)). The guanine signal at $1487 \mathrm{~cm}^{-1}$ (detected as a shoulder of the strong $\delta\left(\mathrm{CH}_{2}\right)_{\text {lipids }}$ band at $1448 \mathrm{~cm}^{-1}$ ) is particularly sensitive to the binding of electrophilic agents (such as cisplatin-like compounds) at the $\mathrm{N}_{7}$ acceptor, having decreased in intensity (nearly disappearing) upon druginteraction. As for the guanine band at $c a .1579 \mathrm{~cm}^{-1}$, it was found to be slightly reduced in the presence of the polynuclear Spm agents, as opposed to the cisplatin-induced blue shift (to $1585 \mathrm{~cm}^{-1}$ ). Additionally, the strong signal centered at $1660 \mathrm{~cm}^{-1}$, encompassing contributions from protein $\nu(\mathrm{C}=\mathrm{O}$ ) (amide I), lipid $\nu(\mathrm{C}=\mathrm{C})$ and DNA $\delta(\mathrm{N}-\mathrm{H})$ modes, (the latter being highly sensitive to the breakage of Watson-Crick H-bonds), raised in intensity in the presence of all three metal complexes studied (as evidenced by the difference spectra in Fig. 2(A)). This intensity increase observed for DNA Raman bands in drug-exposed cells may be explained by a hyperchromic effect upon base unstacking and unpairing. Changes in the bands associated with the DNA phosphate groups are specially informative regarding a drug-prompted distortion of the double helix, namely those at $785 \mathrm{~cm}^{-1}\left(\nu(\mathrm{O}-\mathrm{P}-\mathrm{O})_{\text {backbone }}\right.$ characteristics of B-DNA, combined to cytosine ring breathing), $1092 \mathrm{~cm}^{-1}\left(\nu_{\mathrm{s}}\left(\mathrm{PO}_{2}^{-}\right)\right)$and $1237 \mathrm{~cm}^{-1}\left(\nu_{\text {as }}\left(\mathrm{PO}_{2}{ }^{-}\right)\right)$. The $\nu(\mathrm{O}-\mathrm{P}-\mathrm{O})_{\text {backbone }}$ band suffered an intensity decrease, more evident in the presence of $\mathrm{Pt}_{2} \mathrm{Spm}$ (main discrimination from the control in PC1) as compared to $\mathrm{Pd}_{2} \mathrm{Spm}$ (mostly differentiated in PC2) (Fig. 2(C) and 3). The symmetric stretching mode of the $\mathrm{PO}_{2}{ }^{-}$groups external to the helix backbone (at $1092 \mathrm{~cm}^{-1}$, partially overlapped with the $\nu_{\mathrm{s}}\left(\mathrm{PO}_{2}{ }^{-}\right)$band from phospholipids at $\left.1082 \mathrm{~cm}^{-1}\right)$ showed slight deviations for $\mathrm{Pt}_{2} \mathrm{Spm}\left(1090 \mathrm{~cm}^{-1}\right)$ and $\mathrm{Pd}_{2} \mathrm{Spm}\left(1091 \mathrm{~cm}^{-1}\right)$, as compared to cisplatin $\left(1099 \mathrm{~cm}^{-1}\right.$ ) (Fig. 2(C)). These spectral changes are in agreement with a B- to A-DNA (or ultimately Z-DNA) transition due to covalent drug-binding, ${ }^{23}$ yielding strong crosslinks responsible for disruption of the base stacking and/or base pairing. Apart from the intensity decrease upon drug exposure of the $\nu(\mathrm{O}-\mathrm{P}-$ O) backbone bands ascribed to the native double helix structure (at 785 and 830 $\mathrm{cm}^{-1}$ ), a red shift of the $698 \mathrm{~cm}^{-1}$ signal assigned to B-DNA deoxyguanine was detected, for all tested agents, to about $668 \mathrm{~cm}^{-1}$ (compatible with a B- to A-DNA transition) and $622 \mathrm{~cm}^{-1}$ (reflecting a B- to Z-form rearrangement). Moreover, apart from the B-DNA marker at $830 \mathrm{~cm}^{-1}$, a typical band for A-DNA ${ }^{65}$ was detected at 805,809 and $810 \mathrm{~cm}^{-1}$ respectively for the cisplatin, $\mathrm{Pt}_{2} \mathrm{Spm}$ and $\mathrm{Pd}_{2}$ Spm-containing cells (Fig. 2(C)). These are reliable spectral biomarkers of the metal-based drugs' interaction with DNA and consequent distortion of the DNA backbone, the $\nu\left(\mathrm{PO}_{2}{ }^{-}\right)$modes being particularly responsive to variations in the electrostatic environment of the phosphate group within the double helix.

Changes in the vibrational modes ascribed to cellular proteins (Table 1) were also observed, reflecting a drug effect either by direct interaction (e.g. binding to cytoplasmic proteins) or indirectly (namely via proteolysis during the apoptotic process). In addition, the recognised cytotoxic mechanism of metal-based agents 
involves the binding of high mobility group (HMG) proteins to DNA upon platination- (or palladation)-induced conformational rearrangement of the double helix (precluding repair mechanisms). The most relevant markers associated with protein variations were those at $728 / 757 \mathrm{~cm}^{-1}$ (tryptophan ring breathing), 855 $\mathrm{cm}^{-1}$ (Tyr), 935-940 $\mathrm{cm}^{-1}\left(\nu(\mathrm{CC})_{\text {protein }}, \alpha\right.$-helix), $1003 \mathrm{~cm}^{-1}$ (phenylalanine symmetric ring stretching), $1207 \mathrm{~cm}^{-1}$ ( $\nu$ (CC) from phenylalanine, tryptophan and hydroxyproline), $1127-1158 \mathrm{~cm}^{-1}(\nu(\mathrm{CN})), 1220-1300 \mathrm{~cm}^{-1}$ (amide III, $\nu(\mathrm{CN}) /$ $(\delta(\mathrm{CN}-\mathrm{H}))), 1448 \mathrm{~cm}^{-1}(\delta(\mathrm{CH})$ overlapped with similar modes from lipids) and $1660 \mathrm{~cm}^{-1}$ (predominantly amide I). While the impact on the protein skeletal stretching modes (e.g. $\nu(\mathrm{CN})$ at 1127 and $1157 \mathrm{~cm}^{-1}$ ) was found to be noteworthy for the cells incubated with cisplatin (PC1), it was much less marked for $\mathrm{Pt}_{2} \mathrm{Spm}$ and $\mathrm{Pd}_{2} \mathrm{Spm}$ (PC1 and PC2), for which variance was more significant in the amide III band (Fig. 3(B)). The Trp ring breathing feature, detected at $757 \mathrm{~cm}^{-1}$ in the untreated cells, suffered a slight red shift (to $755 \mathrm{~cm}^{-1}$ ) upon exposure to cisplatin and the Spm complexes (for which this signal was partially overlapped with the one from the thymine ring, Fig. $2(\mathrm{C}))$. As for the $\rho\left(\mathrm{CH}_{2}\right)$ signal from the peptide chains, it was shifted from 883 to $885 \mathrm{~cm}^{-1}$ only in the presence of $\mathrm{Pt}_{2} \mathrm{Spm}$. Additionally, direct binding of the drugs to membrane and cytoplasmic proteins is anticipated to cause variations in their secondary and tertiary structures, reflected in the characteristic features of $\beta$-sheet, random coil and $\alpha$-helix conformations (at 1229-1235 $\mathrm{cm}^{-1}, 1243-1253 \mathrm{~cm}^{-1}$ and $1270-1300 \mathrm{~cm}^{-1}$, respectively, Table 1). These were perceived in the amide III band, namely through changes in the signal characteristics of the $\alpha$-helix signal at $1272 \mathrm{~cm}^{-1}$, primarily in the presence of $\mathrm{Pt}_{2} \mathrm{Spm}\left(1260 \mathrm{~cm}^{-1}\right)$ and $\mathrm{Pd}_{2} \mathrm{Spm}\left(1254 \mathrm{~cm}^{-1}\right)$, evidencing a partial conversion to a random coil structure. Moreover, exposure of side chains containing aromatic residues as a consequence of protein unfolding is suggested to be responsible for the very slight intensity increase of some of the bands ascribed to their ring breathing modes, ${ }^{63}$ which was currently observed only for Phe (Fig. 2(A)). The drug impact on the protein amide I band, in turn, showed to be noticeable for cisplatin, as clearly evidenced by the respective PC1 loading (Fig. 3(B)). In turn, $\mathrm{Pt}_{2} \mathrm{Spm}$ and $\mathrm{Pd}_{2} \mathrm{Spm}$ were found to have a higher effect on the $\delta\left(\mathrm{CH}_{2}\right)$ and $\delta\left(\mathrm{NH}_{2}\right)$ modes from the peptide chains (at $c a .1440$ and $1618 \mathrm{~cm}^{-1}$, Table 1), as shown in the PC2 loading plot. Analysis of the high frequency region of the spectra (Fig. 2(B) and 4) allowed the conclusion that the amide A band at $3290 \mathrm{~cm}^{-1}$ (exclusively due to protein $\nu(\mathrm{NH})$ modes), as well as the amide B signal at $3060 \mathrm{~cm}^{-1}$ (arising from a Fermi resonance between amide I's first overtone and $\nu(\mathrm{NH})$ and hence strongly dependent on intramolecular H-bonds), did not undergo significant changes upon drug exposure, as opposed to the $\mathrm{CH}$ stretching modes of the cellular biomolecules $\left(2850-2960 \mathrm{~cm}^{-1}\right)$.

MDA-MB-231 cells are especially rich in lipids (e.g. glycerophospholipids, known to be increased in cancer cells ${ }^{66}$ ). The direct drug impact on these cell constituents was reflected as an increase of the intense Raman feature centered at $1448 \mathrm{~cm}^{-1}\left(\delta\left(\mathrm{CH}_{2}\right)\right)$, particularly for $\mathrm{Pt}_{2} \mathrm{Spm}$, as well as of the bands at 2850-2960 $\mathrm{cm}^{-1}$, clearly evidenced in the difference spectra obtained for all the tested drugs (Fig. 2(A) and (B)). This may also be inferred by analysis of the loading plots corresponding to $\mathrm{Pt}_{2} \mathrm{Spm}$ and $\mathrm{Pd}_{2} \mathrm{Spm}$ (respectively in PC1 and PC2, Fig. 3(B)). However, since $\mathrm{CH}_{2}$ deformations from cellular lipids occur in the same wavenumber interval as similar modes from proteins and carbohydrates (Table 1), as well as from the spermine polyamine ligand (Fig. 1), PCA differentiation should 

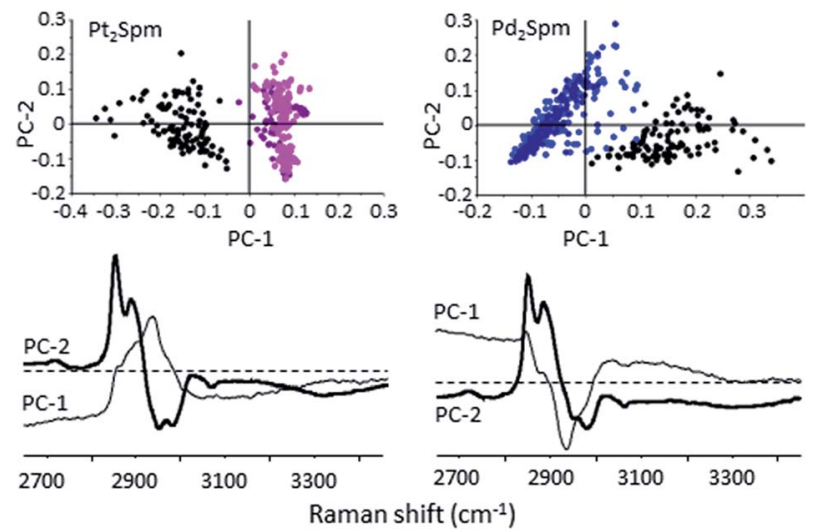

- Control $\bullet \mathrm{Pt}_{2} \mathrm{Spm} 4 \mu \mathrm{M} \quad-\mathrm{Pt}_{2} \mathrm{Spm} 8 \mu \mathrm{M} \quad \mathrm{Pd}_{2} \mathrm{Spm} 4 \mu \mathrm{M} \quad \bullet \mathrm{Pd}_{2} \mathrm{Spm} 8 \mu \mathrm{M}$

Fig. 4 PCA score and loading plots of Raman data (fixed cells, Bruker Senterra/532 nm, 2650-3450 $\mathrm{cm}^{-1}$ ) for $\mathrm{Pt}_{2} \mathrm{Spm}$ - and $\mathrm{Pd}_{2} \mathrm{Spm}$-treated (4 and $8 \mu \mathrm{M}$ ) MDA-MB-231 cells versus the control (the dashed horizontal lines indicates zero loading).

be interpreted with care in this region. The PC2 loading plot for $\mathrm{Pd}_{2} \mathrm{Spm}$, for instance, also showed a very marked discrimination according to protein and carbohydrate $\mathrm{CH}_{2}$ deformations $\left(c a .1430 \mathrm{~cm}^{-1}\right.$ ). The highest frequency spectral region is therefore more suited for this analysis, the drug-induced changes observed in the typical $\nu\left(\mathrm{CH}_{2}\right)\left(2850-2935 \mathrm{~cm}^{-1}\right)$ and $\nu\left(\mathrm{CH}_{3}\right)\left(2960 \mathrm{~cm}^{-1}\right)$ vibrational modes from lipids being reflected in the clear separation from the untreated cells along PC1, for all agents investigated: the loadings corresponding to the $(\mathrm{CH})$ stretching modes from methyl groups being positive for cisplatin and negative for both spermine complexes (Fig. 4). This evidences different biochemical impacts induced by these mono- and dinuclear agents on lipid terminal moieties $\left(\mathrm{CH}_{3}\right)$ versus $-\left(\mathrm{CH}_{2}\right)_{n}-/-\left(\mathrm{HC}=\mathrm{CH}-\mathrm{CH}_{2}\right)_{n}-$ chains, which is in accordance with the presence of the alkyl moieties within the ligand in the $\mathrm{Pt}_{2} \mathrm{Spm}$ and $\mathrm{Pd}_{2} \mathrm{Spm}$ complexes that are prone to interact efficiently with the hydrophobic chain of lipid molecules (as opposed to $\mathrm{Pt}\left(\mathrm{NH}_{3}\right)_{2} \mathrm{Cl}_{2}$ ). Regarding membrane lipids, it was possible to identify changes in the vibrational mode ascribed to their phosphate-ester headgroups, at $1732 \mathrm{~cm}^{-1}$, that was shifted to $1739 \mathrm{~cm}^{-1}$ for $\mathrm{Pt}_{2} \mathrm{Spm}$ but hardly detectable (at $c a .1742 \mathrm{~cm}^{-1}$ ) for cisplatin- and $\mathrm{Pd}_{2}$ Spm-treated cells. The $\nu$ (COC) modes from glycosidic bonds in glycolipids, centered at $938 \mathrm{~cm}^{-1}$, were found to be deviated to $934 \mathrm{~cm}^{-1}$ for cisplatin and $\mathrm{Pd}_{2} \mathrm{Spm}$, and to $931 \mathrm{~cm}^{-1}$ for $\mathrm{Pt}_{2} \mathrm{Spm}$. Moreover, the signal at $1158 \mathrm{~cm}^{-1}$, characteristic of the $\mathrm{N}\left(\mathrm{CH}_{3}\right)_{3}{ }^{+}$choline group (e.g. from phosphatidylcholine and sphingomyelin, two main cell membrane constituents), experienced a shift to $1163 \mathrm{~cm}^{-1}$ for the cisplatin-exposed cells and an intensity decrease for the samples exposed to the dinuclear Spm chelates. This may be indicative of the formation of membrane vesicles, as a way for the cell to remove toxins (e.g. the administered compounds) by exocytosis. Overall, the drug effect on cellular lipids results from an interplay of several (sometimes disparate) factors, such as an increase in neutral lipids (associated with cisplatin's nephrotoxicity), an 
enhanced lipid peroxidation, and a reduction in the total lipid content due to membrane degradation and decreased cell viability.

Fig. 3(A) displays the unsupervised PCA analysis considering all agents under study, allowing the identification of discrimination according to PC2 that represents variance in protein, lipids and DNA (specifically $\delta\left(\mathrm{NH}_{2}\right)$, and ring modes from bases and deoxyribose), with a slight overlap between drug-exposed and control cells (mostly for cisplatin). Apart from this distinction between control and treated cells, it was possible to separate each of the three drugs currently tested based on their effect on the cell chemical profile, as compared to the control (Fig. 2 and 3), reflecting the previously described drug-dependent response. Differentiation was achieved in PC1 for cisplatin and $\mathrm{Pt}_{2} \mathrm{Spm}$, while for $\mathrm{Pd}_{2} \mathrm{Spm}$ it was attained in PC2 for the lowest doses and in PC1 for $8 \mu \mathrm{M}$ (Fig. 3(B) and (C)). For cisplatin-treated samples the main impact was observed on DNA and proteins, with an effect on lipids being detected only for $8 \mu \mathrm{M}$. The dinuclear Pt(II) complex, in turn, was responsible for a strong effect on lipids, already at the lowest concentration tested $(2 \mu \mathrm{M})$, also evidenced through changes in the corresponding high energy $\nu\left(\mathrm{CH}_{2}\right)$ modes. In turn, the effect on proteins (noticeable in PC1 and PC2) was only verified for concentrations equal to $4 \mu \mathrm{M}$ or higher. At 8 $\mu \mathrm{M}$ there was a small effect on RNA (bands centered at $879 \mathrm{~cm}^{-1}$ ). $\mathrm{Pd}_{2} \mathrm{Spm}$ produced a noteworthy impact on proteins, for all concentrations tested. As to the $\mathrm{Pd}_{2} \mathrm{Spm}$-induced variance on lipids and DNA, it was significant for $4 \mu \mathrm{M}$ and did not increase at $8 \mu \mathrm{M}$ (Fig. 3(B) and (C)).

A dose-dependent effect was uncovered by separate analysis of the data measured for each compound, a significantly improved discrimination having been achieved for higher concentrations, as expected (Fig. 3(B) and (C)). Comparing the results for the $\mathrm{Pt}_{2} \mathrm{Spm}$ - and $\mathrm{Pd}_{2} \mathrm{Spm}$-treated cells versus the
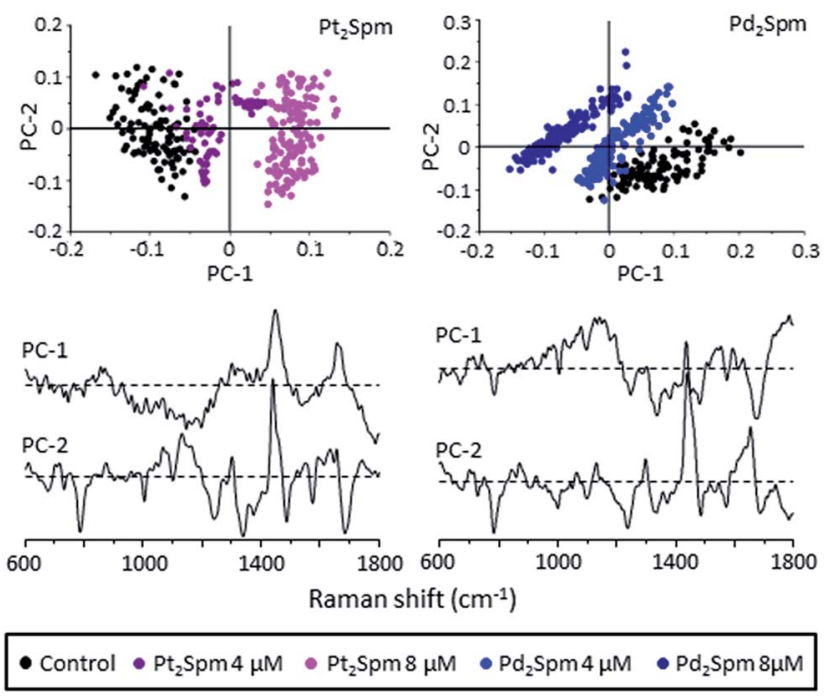

Fig. 5 PCA score and loading plots of Raman data (fixed cells, Bruker Senterra/532 nm, 600-1800 $\mathrm{cm}^{-1}$ ) for $\mathrm{Pt}_{2} \mathrm{Spm}-$ and $\mathrm{Pd}_{2} \mathrm{Spm}$-treated (4 and $8 \mu \mathrm{M}$ ) MDA-MB-231 cells versus the control (for clarity the loadings are offset, the dashed horizontal lines indicating zero loading). 
control, for 4 and $8 \mu \mathrm{M}$ (Fig. 5), allowed the conclusion that separation from the control as well as between both $\mathrm{Pt}_{2} \mathrm{Spm}$ concentrations occurred along PC1, the discriminant peaks corresponding predominantly to DNA and lipids. For $\mathrm{Pd}_{2} \mathrm{Spm}$, this distinction was not as noticeable (increasing with drug concentration), and occurred in PC1 reflecting DNA (at 785 and $c a .1320 \mathrm{~cm}^{-1}$ ) and protein components (at $c a .1150$ and $1660 \mathrm{~cm}^{-1}$ ), with a very small variance for the lipids (at $1448 \mathrm{~cm}^{-1}$ ). Interestingly, while in the fingerprint region discrimination was achieved between 4 and $8 \mu \mathrm{M}$ concentrations for both Pt- and Pd-complexes (Fig. 5), in the highest frequency range, mainly reflecting the impact on lipids, no differentiation was observed between distinct drug doses for $\mathrm{Pt}_{2} \mathrm{Spm}$ and a very small separation was detected for $\mathrm{Pd}_{2} \mathrm{Spm}$ (Fig. 4). Hence, the effect on lipids appears to become dose-independent above $4 \mu \mathrm{M}$, which implies a higher sensitivity of the cellular lipid content to the administered drugs as compared to the other biomolecules, a maximum effect being attained for lower concentrations of the chemotherapeutic agent, particularly for $\mathrm{Pt}_{2} \mathrm{Spm}$.

Discrimination between the two dinuclear spermine complexes was also attained, through PC2 (Fig. 6) that predominantly represents the cellular DNA (at $678,728,746,785,974$, ca. 1180, 1315, 1420, 1490 and $1620-1660 \mathrm{~cm}^{-1}$ ) and RNA (at 812 and $920-940 \mathrm{~cm}^{-1}$ ). This reflects the distinct impact of each chelate on nucleic acids, suggesting the occurrence of different pathways for cytotoxicity according to the nature of the metal centre.

In summary, the Raman spectra presently obtained for the MDA-MB-231 cells may be resolved into distinct regions of statistically significant spectral biomarkers which were found to undergo variations upon drug treatment, corresponding to different biochemical impacts. The overall effect of the tested agents on the vibrational features from the main cellular components is consistent with changes in DNA, as well as in cytoplasmic proteins and lipids, and the onset of apoptosis involving chromatin condensation, DNA fragmentation, membrane blebbing, protein proteolysis (e.g. in the cytoskeleton) and lipid accumulation. The distinct outcomes on the cell chemical content currently

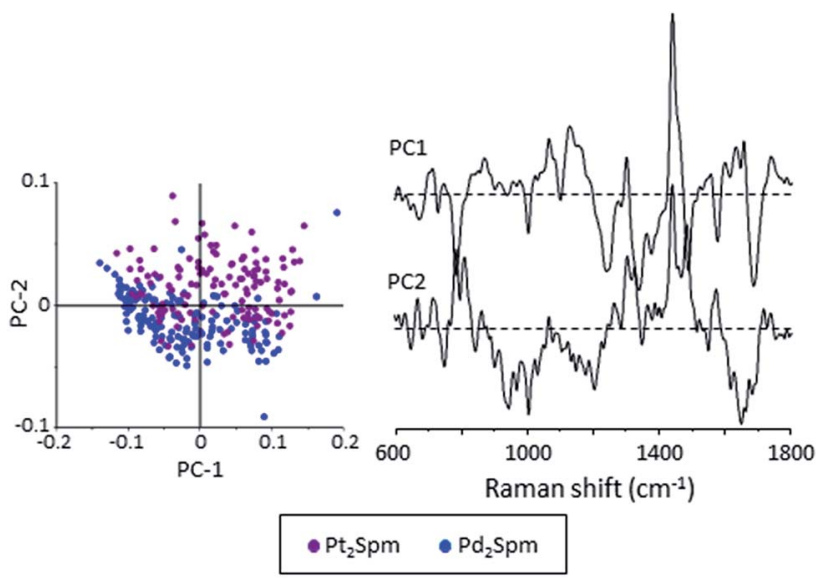

Fig. 6 PCA score and loading plots of Raman data (fixed cells, Bruker Senterra/532 nm, 600-1800 cm ${ }^{-1}$ ) for drug-treated MDA-MB-231 cells: $\mathrm{Pt}_{2} \mathrm{Spm}$ versus $\mathrm{Pd}_{2} \mathrm{Spm}(8 \mu \mathrm{M}$ ) (for clarity the loadings are offset, the dashed horizontal lines indicating zero loading). 
unveiled for $\mathrm{Pt}_{2} \mathrm{Spm}$ and $\mathrm{Pd}_{2} \mathrm{Spm}$ may be indicative of the occurrence of alternative pathways of cytotoxicity for the palladium complex, as opposed to a preferentially apoptotic mechanism of cell death induced by its platinum homologue (as is widely accepted for the Pt-drugs in clinical use - cisplatin, carboplatin and oxaliplatin). The results presently obtained for cisplatin are in accordance with reported Raman studies on the cisplatin effect on human lung adenocarcinoma cells, ${ }^{\mathbf{6 2 , 6 3}}$ despite the longer drug exposure time considered by these authors - $96 \mathrm{~h}$ as compared to the $48 \mathrm{~h}$ incubation period used in the current work. Additionally, the chemical variations associated with the apoptotic process presently described agree with time-course Raman imaging experiments during apoptosis performed in the same breast cancer cell line, maintained under physiological conditions. ${ }^{50}$

\section{C.2 SR-infrared microspectroscopy}

The main infrared bands presently observed for the MDA-MB-231 cells are depicted in Fig. 1, clearly showing the signals assigned to the protein characteristic modes amide A and amide II $\left(\delta(\mathrm{CN}-\mathrm{H}) / \nu(\mathrm{CN})\right.$ at $\left.c a .1550 \mathrm{~cm}^{-1}\right)$, as well as to the ester groups from phospholipids ( $c a .1730 \mathrm{~cm}^{-1}$, Table 1). Infrared signatures from untreated and drug-treated cells were successfully retrieved from the data, evidencing a good PCA discrimination on the basis of the distinct biochemical profile observed for each condition. Since the main conclusions are in accordance with the Raman results previously described in detail, the following discussion will only emphasize the specific effects unveiled by IRMS analysis.

In view of the optical substrate transmission range $(0.35-10 \mu \mathrm{m}$ wavelength) it was not possible to reliably explore the data below $c a .1100 \mathrm{~cm}^{-1}$, i.e. the nucleic acid region was strongly affected by the cut off of the $\mathrm{CaF}_{2}$ substrate at 1000 $\mathrm{cm}^{-1}{ }^{.51}$ Spectra were therefore truncated between 1100 and $1800 \mathrm{~cm}^{-1}$ for baseline correction prior to PCA analysis. When applying the PCA, the spectral interval from 1100 to $1250 \mathrm{~cm}^{-1}$ was not found to yield significant information. PCA applied to the spectral range $1250-1800 \mathrm{~cm}^{-1}$ showed the largest variability in the data, allowing us to distinguish the impact of each drug type effectively. Actually, the score and loading plots extracted for PC2 and PC3 (Fig. 7) evidenced significant differences between cisplatin and the platinum and palladium-spermine complexes. In each case, good discrimination was observed along PC3, enabling separation between the untreated control and the drug-treated cells: while there was some overlap in the scatter plots, two centroids could be clearly distinguished. No other principal components were able to successfully discriminate between the control and drug-exposed cells. The loading plot along PC3 for the cisplatin-containing samples displayed an intense peak at $1659 \mathrm{~cm}^{-1}$ (amide I) and a relatively weak band at $1556 \mathrm{~cm}^{-1}$ (amide II), reflecting a clear effect on proteins. Furthermore, two distinct signals ascribed to $\nu(\mathrm{C}=\mathrm{O})$ modes appeared, respectively from amino acid side chains and antiparallel $\beta$-sheet conformations (at $1690 \mathrm{~cm}^{-1}$ ), and from phospholipid ester groups (at $1741 \mathrm{~cm}^{-1}$, Table 1). In addition to these peaks observed for the cisplatin-exposed samples, further bands were detected upon incubation with the spermine complexes, at 1460 and 1628 $\mathrm{cm}^{-1}$, due to anti-symmetric $\mathrm{CH}_{2}$ scissoring from lipids and to the amide I protein mode ( $\beta$-sheet parallel), respectively. The band at $1741 \mathrm{~cm}^{-1}$ for the cisplatintreated cells was found to be slightly shifted to $1728 \mathrm{~cm}^{-1}$ in the presence of $\mathrm{Pt}_{2} \mathrm{Spm}$ and $\mathrm{Pd}_{2} \mathrm{Spm}$, possibly as a consequence of drug interaction with the cell 

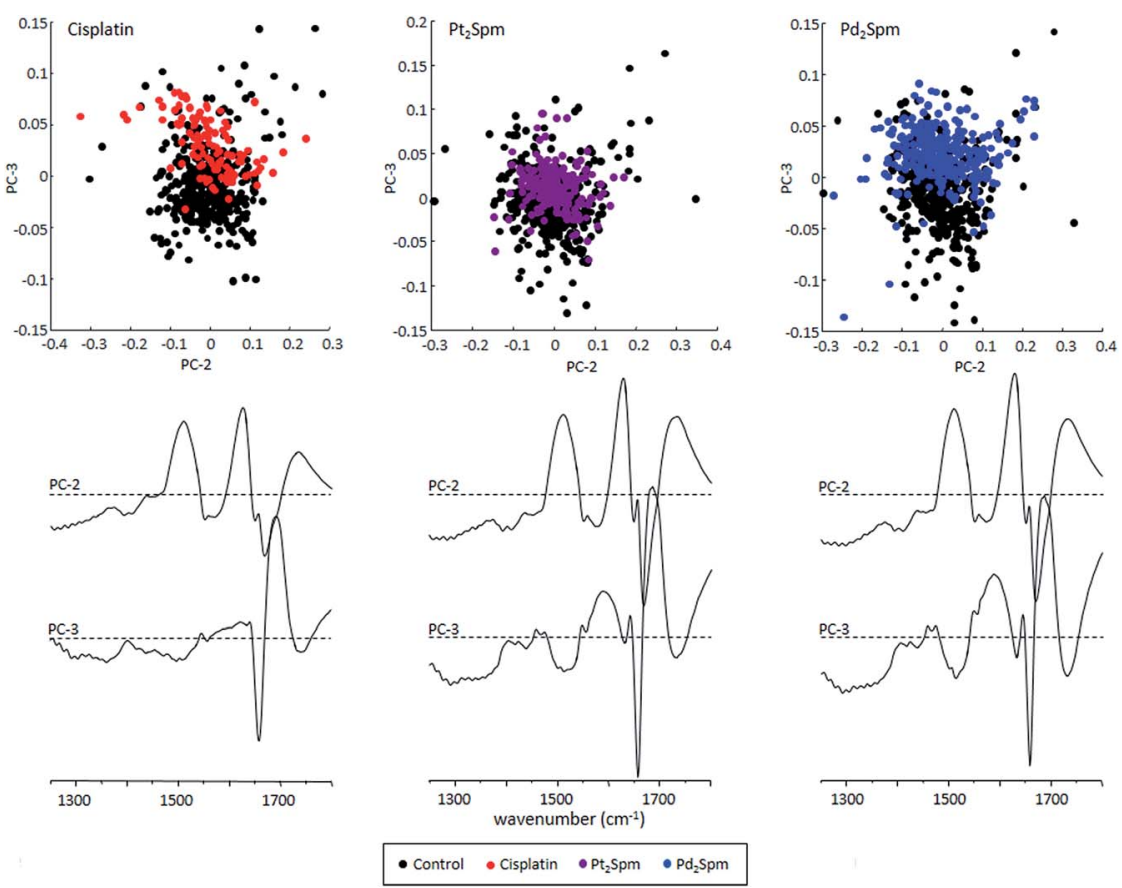

Fig. 7 PCA score and loading plots of FTIR data (fixed cells, MIRIAM, 1250-1800 cm-1) for cisplatin-, $\mathrm{Pt}_{2} \mathrm{Spm}$ - and $\mathrm{Pd}_{2} \mathrm{Spm}$-treated $(4 \mu \mathrm{M}) \mathrm{MDA}-\mathrm{MB}-231$ cells versus the control (for clarity the loadings are offset, the dashed horizontal lines indicating zero loading).

membrane (phospholipid moieties). These results indicate the significant impact of the Pt(II) and $\mathrm{Pd}(\mathrm{II})$-polyamine agents on the cellular proteins and lipids, as verified by Raman. Strong similarities were apparent in the loading plots for PC3 for both $\mathrm{Pt}_{2} \mathrm{Spm}$ and $\mathrm{Pd}_{2} \mathrm{Spm}$, which suggests an identical impact of these drugs on the MDA-MB-231 cells, differing from cisplatin mostly in the bands ascribed to the $\mathrm{CH}_{2}$ stretching modes from lipids ( $c a .1450 \mathrm{~cm}^{-1}$ ). Also, the differences exposed by comparison with the cisplatin loading plot indicate that the activity of $\mathrm{Pt}_{2} \mathrm{Spm}$ and $\mathrm{Pd}_{2} \mathrm{Spm}$ follows a different pathway, which is to be expected since the biochemical interaction of these dinuclear highly flexible complexes to DNA and other cellular components is likely to occur via a somewhat distinct mechanism to that of mononuclear cisplatin.

The effect of drug exposure on the cellular lipid constituents was also assessed by applying PCA to the $2650-3450 \mathrm{~cm}^{-1}$ spectral region (comprising the amide A and lipid $\mathrm{CH}$ stretching vibrational modes). Fig. 8 depicts the score and loading plots for the cells exposed to each of the three tested drugs versus the control, showing some separation along PC2. For each compound, these plots display predominantly positive scores while the untreated controls are chiefly negative, reflecting different modes of action. Similar profiles were obtained in the PC2 loadings, the main differentiating signal from the control being the one centered at $2960 \mathrm{~cm}^{-1}$ ascribed to methyl group stretching (mainly from the lipids). The increase in this band's intensity upon drug exposure is in agreement with the PCA plots obtained from the Raman spectra (Fig. 4). The amide A $\left(3290 \mathrm{~cm}^{-1}\right)$ and amide $\mathrm{B}\left(3060 \mathrm{~cm}^{-1}\right)$ protein modes were also found to undergo drug-induced 

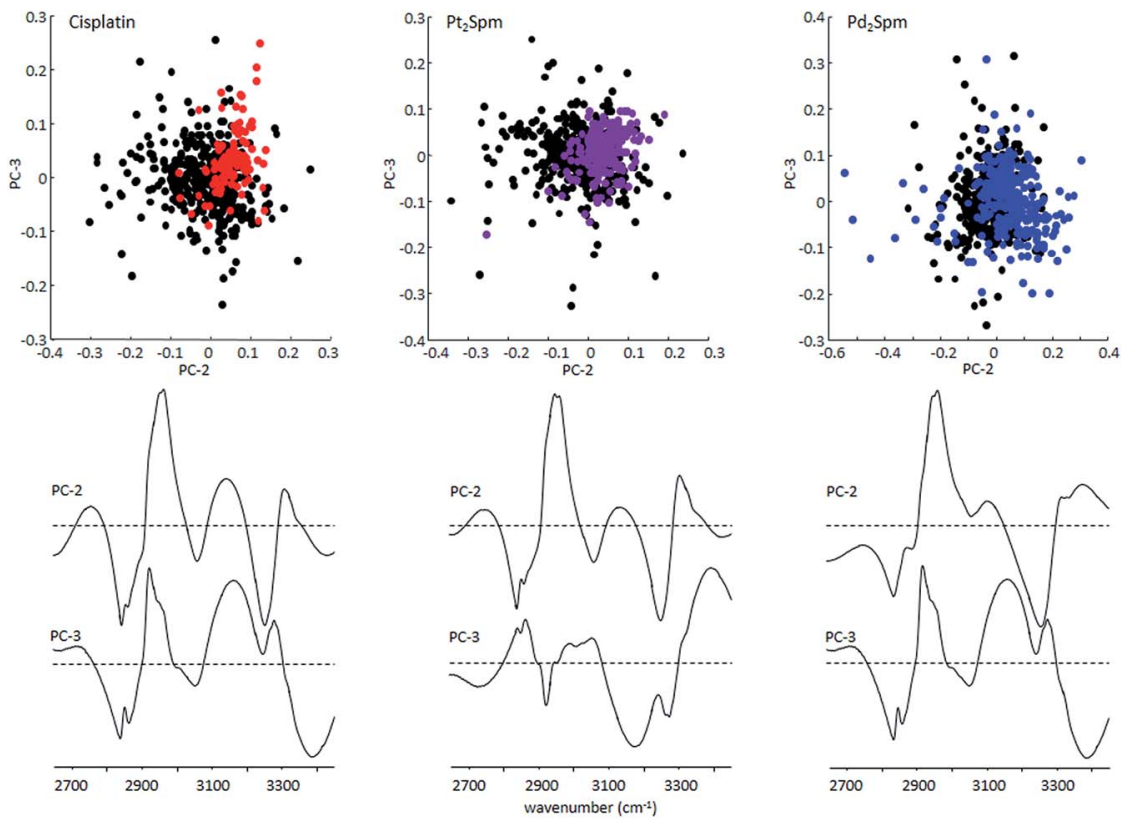

- Control $\bullet$ Cisplatin $\bullet \mathrm{Pt}_{2} \mathrm{Spm} \quad \bullet \mathrm{Pd}_{2} \mathrm{Spm}$

Fig. 8 PCA score and loading plots of FTIR data (fixed cells, MIRIAM, $2650-3450 \mathrm{~cm}^{-1}$ ) for cisplatin-, $\mathrm{Pt}_{2} \mathrm{Spm}$ - and $\mathrm{Pd}_{2} \mathrm{Spm}$-treated (4 $\mu \mathrm{M}$ ) MDA-MB-231 cells versus the control (for clarity the loadings are offset, the dashed horizontal lines indicating zero loading).

changes (namely an intensity decrease) for both Spm complexes, supporting an impact on proteins. The effect on these particular features could only be clearly evidenced by infrared, since these are weak signals in Raman (Fig. 2).

The effect of changing the metal centre within the spermine chelates was also probed, in the high frequency spectral range. The biological effect on the treated
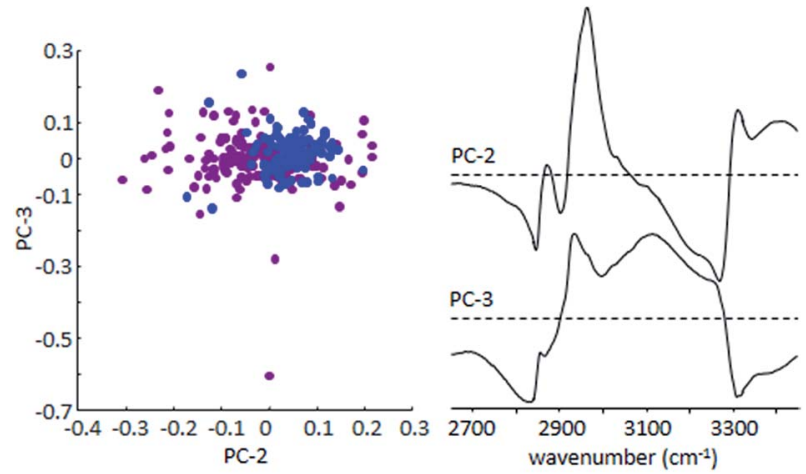

- $\mathrm{Pt}_{2} \mathrm{Spm} \quad \mathrm{Pd}_{2} \mathrm{Spm}$

Fig. 9 PCA score and loading plots of FTIR data (fixed cells, MIRIAM, $2650-3450 \mathrm{~cm}^{-1}$ ) for drug-treated MDA-MB-231 cells: $\mathrm{Pt}_{2} \mathrm{Spm}$ versus $\mathrm{Pd}_{2} \mathrm{Spm}(4 \mu \mathrm{M})$ (for clarity the loadings are offset, the dashed horizontal lines indicating zero loading). 
cells (for a $4 \mu \mathrm{M}$ drug concentration) was brought out on examination of the score and loading plots represented in Fig. 9, a good discrimination having been achieved between $\mathrm{Pt}_{2} \mathrm{Spm}$ and $\mathrm{Pd}_{2} \mathrm{Spm}$ along PC2. Major variance was observed in the typical bands from lipids ( 2850 to $2960 \mathrm{~cm}^{-1}$ ), as well as in a broad features due to the amide A mode, once more evidencing an impact on proteins and lipids.

\section{Conclusions}

The present study aimed at applying optical vibrational spectroscopy methods Raman and synchrotron-radiation infrared microspectroscopy (SR-IRMS) - for the investigation and measurement of the metabolic impact of and cellular response to two potential cisplatin-like anticancer agents varying only in the nature of the metal centre $-\mathrm{Pt}_{2} \mathrm{Spm}$ and $\mathrm{Pd}_{2} \mathrm{Spm}$. These were administered separately to human metastatic breast cancer cells (MDA-MB-231), and distinctive spectral signatures were obtained as a function of drug concentration $(2-8 \mu \mathrm{M})$, for a $48 \mathrm{~h}$ exposure period. The widely used chemotherapeutic drug cisplatin (with a known mode of action) was chosen as a reference compound. Although the tested chemotherapeutic agents were not tracked intracellularly, this approach yielded an accurate description of variations in cellular biochemistry, with molecular specificity, in the presence of each of the compounds under study, allowing the identification of vibrational bands (spectral biomarkers) assigned to specific drug-elicited effects and to the cell response to this perturbation.

The MDA-MB-231 cell line showed to be sensitive to the tested compounds, being prompted to apoptosis by incubation with the metal complexes (for $48 \mathrm{~h}$ ). Drug exposure triggered both a direct biochemical effect and a physiological response from the cell, which were reflected in the cellular vibrational signature but not always clearly distinguished. Actually, while changes in the vibrational features from DNA could be unmistakably ascribed to direct drug binding, variations in the bands assigned to lipids and proteins were the combined outcome of direct drug interaction and the cellular reaction to the chemotherapeutic insult (e.g. formation of membrane vesicles for exocytosis or biochemical events following apoptotic stimuli such as protein degradation).

The detected changes in the infrared and Raman signatures of particular intracellular constituents triggered by the Pt- and Pd-spermine complexes under study were compared to the control cells, as well as to the cisplatin-exposed samples. Unsupervised principal components analysis of the data enabled us to clearly distinguish between drug-treated and untreated cells. Additionally, it was possible to discriminate between groups of data and correlate them with different chemotherapeutic conditions, regarding concentration and type of drug - either $\mathrm{Pt}(\mathrm{II})$ - or $\mathrm{Pd}(\mathrm{II})$-based, mononuclear (cisplatin) or dinuclear ( $\mathrm{Pt}_{2} \mathrm{Spm}$ and $\left.\mathrm{Pd}_{2} \mathrm{Spm}\right)$.

Both infrared and Raman data reflected drug- and dose-dependent responses, the main effect on intracellular metabolism being on lipids, DNA and proteins. Bands associated with the B-DNA native form suffered a decrease in intensity compatible with drug-induced conformational rearrangements, upon formation of stable adducts within the double helix. In particular, the vibrational modes of the DNA deoxyribose-phosphate backbone, which are very sensitive to base stacking and base-pairing, were suitable markers of drug activity for the metalbased agents currently investigated. When compared to cisplatin and $\mathrm{Pt}_{2} \mathrm{Spm}$, $\mathrm{Pd}_{2}$ Spm elicited a significant effect on the DNA backbone conformation (detected 
by Raman) and on proteins (in agreement with previously reported effects on the cytoskeleton ${ }^{16}$ ). The cellular lipid components, in turn, appeared to be more sensitive to the Pt-spermine complex, not only relative to its palladium homologue but also to cisplatin. This effect on lipids is noteworthy, in view of the close link between lipid accumulation and breast cancer aggressiveness and metastatic spread.$^{67}$ These findings are consistent with the mode of action generally accepted for cisplatin and cisplatin-like DNA groove-binding agents, but also unveiled alternative pathways of cytotoxicity for the spermine dinuclear complexes, that also appear to differ according to the nature of the metal centres (Pt(II) or Pd(II)).

The results obtained along this work were related with a thorough conformational analysis of the newly synthesised metal-based agents (by Raman, IR and INS coupled to theoretical approaches) ${ }^{18-24,34-36}$ and with biological assays for the evaluation of cytotoxicity performed alongside on the same systems - cell growth and viability inhibition, as well as anti-angiogenic and anti-metastatic abili-

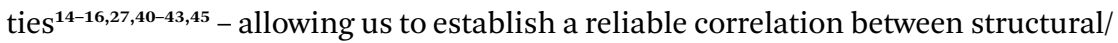
conformational features, cytotoxic activity and impact on cellular metabolism. This data, coupled to previous INS and EXAFS studies on drug-DNA adducts (carried out at ISIS and DLS ${ }^{18,21,23,24}$ ), will pave the way for future work on other promising cisplatin-like anticancer agents (both Pt(II) and Pd(II)) which have been studied by the team in the last few years, as well as on distinct human cancer cells. In addition, experiments are envisaged to monitor the drugs biodistribution within the cell, by differentiating the responses in different subcellular regions as well as through the use of synchrotron radiation FTIR microspectroscopy for obtaining high spatial resolution chemical images on single cells. Furthermore, quasi-elastic neutron spectroscopy studies are under way for probing water within living human cancer cells, with a view to ascertain differences upon drug incubation (possibly unveiling secondary targets of drug action).

This type of study is expected to contribute to the elucidation of potentially novel pathways of cytotoxicity for tailored $\mathrm{Pt}$ (II) and $\mathrm{Pd}$ (II) polynuclear compounds, leading to diverse and improved pharmacological properties coupled to minimal acquired resistance, and hopefully allowing the identification and prediction of the cellular response to chemotherapy.

\section{Acknowledgements}

The Portuguese Foundation for Science and Technology - UID/MULTI/00070/ 2013, PhD fellowship SFRH/BD/72851/2010 and Project PTDC/QEQ-MED/1890/ 2014. CICECO, the University of Aveiro (PT), for access to the FT-Raman spectrometer. The STFC Rutherford Appleton Laboratory (UK), for access to neutron beam facilities (RB 520092, 1320035), work supported by the European Commission $-7^{\text {th }}$ Framework Programme/Key Action Strengthening the European Research Area, Research Infrastructures (CP-CSA_INFRA-2008-1.1.1 No. 226507NMI3). Diamond Light Source (UK), for time on B22/MIRIAM (SM10065), under the European programme Calypso FP7.

\section{References}

1 J. Ferlay, I. Soerjomataram, M. Ervik, R. Dikshit, S. Eser, C. Mathers, M. Rebelo, D. M. Parkin, D. Forman and F. Bray, GLOBOCAN 2012 v1.0, Cancer Incidence 
and Mortality Worldwide: IARC CancerBase No. 11, International Agency for Research on Cancer, Lyon, France, 2013, http://globocan.iarc.fr, accessed 14 October 2014.

2 B. Weigelt, J. L. Peterse and L. J. van't Veer, Nat. Rev. Cancer, 2005, 5, 591.

3 H. Doppler and P. Storz, Cell Metab., 2015, 22, 536.

4 M. P. Decatris, S. Sundar and K. J. O'Byrne, Cancer Treat. Rev., 2004, 30, 53.

5 B. Rosenberg, L. Vancamp and T. Krigas, Nature, 1965, 205, 698.

6 B. Rosenberg, L. VanCamp, J. E. Trosko and V. H. Mansour, Nature, 1969, 222, 385.

7 N. J. Wheate, S. Walker, G. E. Craig and R. Oun, Dalton Trans., 2010, 39, 8113.

8 L. Kelland, Nat. Rev. Cancer, 2007, 7, 573.

9 N. P. Farrell, Curr. Top. Med. Chem., 2011, 11, 2623.

10 J. Reedijk, Pure Appl. Chem., 2011, 83, 1709.

11 S. Komeda, Metallomics, 2011, 3, 650.

12 M. P. M. Marques, ISRN Spectrosc., 2013, 2013, 29.

13 C. S. Matos, A. L. M. Batista de Carvalho, R. P. Lopes and M. P. M. Marques, Curr. Med. Chem., 2012, 19, 4678.

14 T. M. Silva, S. Andersson, S. K. Sukumaran, M. P. Marques, L. Persson and S. Oredsson, PLoS One, 2013, 8, e55651.

15 T. M. Silva, S. M. Fiuza, M. P. M. Marques, L. Persson and S. Oredsson, Amino Acids, 2014, 46, 339.

16 S. M. Fiuza, J. Holy, L. A. E. Batista de Carvalho and M. P. M. Marques, Chem. Biol. Drug Des., 2011, 77, 477.

17 A. M. Florea and D. Busselberg, Cancers, 2011, 3, 1351.

18 L. A. E. Batista de Carvalho, M. P. M. Marques, C. Martin, S. F. Parker and J. Tomkinson, ChemPhysChem, 2011, 12, 1334.

19 T. M. Silva, S. Oredsson, L. Persson, P. Woster and M. P. M. Marques, J. Inorg. Biochem., 2012, 108, 1.

20 A. L. M. Batista de Carvalho, S. M. Fiuza, J. Tomkinson, L. A. E. Batista de Carvalho and M. P. M. Marques, Spectrosc. Int. J., 2012, 27, 403.

21 M. P. M. Marques, R. Valero, S. F. Parker, J. Tomkinson and L. A. E. Batista de Carvalho, J. Phys. Chem. B, 2013, 117, 6421.

22 I. Lamego, I. F. Duarte, M. P. M. Marques and A. M. Gil, J. Proteome Res., 2014, 13, 6033.

23 M. P. M. Marques, D. Gianolio, G. Cibin, J. Tomkinson, S. F. Parker, R. Valero, R. P. Lopes and L. A. E. Batista de Carvalho, Phys. Chem. Chem. Phys., 2015, 17, 5155.

24 S. M. Fiuza, A. M. Amado, S. F. Parker, M. P. M. Marques and L. A. E. Batista de Carvalho, New J. Chem., 2015, 39, 6274.

25 I. F. Duarte, I. Lamego, J. Marques, M. P. M. Marques, B. J. Blaise and A. M. Gil, J. Proteome Res., 2010, 9, 5877.

26 O. Corduneanu, A. M. Chiorcea-Paquim, S. M. Fiuza, M. P. M. Marques and A. M. Oliveira-Brett, Bioelectrochemistry, 2010, 78, 97.

27 O. Corduneanu, A. M. Chiorcea-Paquim, V. Diculescu, S. M. Fiuza, M. P. M. Marques and A. M. Oliveira-Brett, Anal. Chem., 2010, 82, 1245.

28 I. Notingher, Sensors, 2007, 7, 1343.

29 Z. Farhane, F. Bonnier, A. Casey and H. J. Byrne, Analyst, 2015, 140, 5212.

30 A. Marcelli, A. Cricenti, W. M. Kwiatek and C. Petibois, Biotechnol. Adv., 2012, 30, 1390. 
31 M. J. Baker, J. Trevisan, P. Bassan, R. Bhargava, H. J. Butler, K. M. Dorling, P. R. Fielden, S. W. Fogarty, N. J. Fullwood, K. A. Heys, C. Hughes, P. Lasch, P. L. Martin-Hirsch, B. Obinaju, G. D. Sockalingum, J. Sule-Suso, R. J. Strong, M. J. Walsh, B. R. Wood, P. Gardner and F. L. Martin, Nat. Protoc., 2014, 9, 1771.

32 M. Jimenez-Hernandez, M. D. Brown, C. Hughes, N. W. Clarke and P. Gardner, Analyst, 2015, 140, 4453.

33 A. Mignolet, A. Derenne, M. Smolina, B. R. Wood and E. Goormaghtigh, Biochim. Biophys. Acta, Proteins Proteomics, 2016, 1864, 85.

34 S. M. Fiuza, A. M. Amado, M. P. M. Marques and L. A. E. Batista de Carvalho, J. Phys. Chem. A, 2008, 112, 3253.

35 A. M. Amado, S. M. Fiuza, M. P. M. Marques and L. A. E. Batista de Carvalho, J. Chem. Phys., 2007, 127, 185104.

36 S. M. Fiuza, A. M. Amado, H. F. Dos Santos, M. P. M. Marques and L. A. E. Batista de Carvalho, Phys. Chem. Chem. Phys., 2010, 12, 14309.

37 VIBIMA, http://www.uc.pt/en/iii/infrastructures/, accessed 18 September 2015.

38 Diamond Light Source, http://www.diamond.ac.uk/, accessed 18 September 2015.

39 G. Cinque, M. Frogley, K. Wehbe, J. Filik and J. Pijanka, Synchrotron Radiat. News, 2011, 24, 24.

40 M. P. M. Marques, T. Girao, M. C. P. De Lima, A. Gameiro, E. Pereira and P. Garcia, BBA, Biochim. Biophys. Acta, Mol. Cell Res., 2002, 1589, 63.

41 L. J. Teixeira, M. Seabra, E. Reis, M. T. G. da Cruz, M. C. P. de Lima, E. Pereira, M. A. Miranda and M. P. M. Marques, J. Med. Chem., 2004, 47, 2917.

42 S. M. Fiuza, A. M. Amado, P. J. Oliveira, V. A. Sardao, L. A. E. Batista de Carvalho and M. P. M. Marques, Lett. Drug Des. Discovery, 2006, 3, 149.

43 A. S. Soares, S. M. Fiuza, M. J. Goncalves, L. A. E. Batista de Carvalho, M. Paula, M. P. M. Marques and A. M. Urbano, Lett. Drug Des. Discovery, 2007, 4, 460.

44 A. Tassoni, N. Bagni, M. Ferri, M. Franceschetti, A. Khomutov, M. P. Marques, S. M. Fiuza, A. R. Simonian and D. Serafini-Fracassini, Plant Physiol. Biochem., 2010, 48, 496.

45 R. Tummala, P. Diegelman, S. M. Fiuza, L. A. E. Batista de Carvalho, M. P. M. Marques, D. L. Kramer, K. Clark, S. Vujcic, C. W. Porter and L. Pendyala, Oncol. Rep., 2010, 24, 15.

46 G. Codina, A. Caubet, C. Lopez, V. Moreno and E. Molins, Helv. Chim. Acta, 1999, 82, 1025.

47 ISIS-STFC, http://www.isis.stfc.ac.uk/instruments/tosca/, accessed 18 September 2015.

48 S. F. Parker, C. J. Carlile, T. Pike, J. Tomkinson, R. J. Newport, C. Andreani, F. P. Ricci, F. Sacchetti and M. Zoppi, Phys. B, 1997, 241-243, 154.

49 ECACC, https://www.phe-culturecollections.org.uk/products/celllines/ generalcell/detail.jsp?refId $=92020424 \&$ collection $=$ ecacc_gc, accessed 18 September 2015.

50 A. Zoladek, F. C. Pascut, P. Patel and I. Notingher, J. Raman Spectrosc., 2011, 42, 251.

51 K. Wehbe, J. Filik, M. D. Frogley and G. Cinque, Anal. Bioanal. Chem., 2013, 405, 1311.

52 P. Bassan, A. Kohler, H. Martens, J. Lee, H. J. Byrne, P. Dumas, E. Gazi, M. Brown, N. Clarke and P. Gardner, Analyst, 2010, 135, 268. 
53 P. Bassan, A. Sachdeva, A. Kohler, C. Hughes, A. Henderson, J. Boyle, J. H. Shanks, M. Brown, N. W. Clarke and P. Gardner, Analyst, 2012, 137, 1370.

54 S. Dasari and P. B. Tchounwou, Eur. J. Pharmacol., 2014, 740, 364.

55 E. Gazi, J. Dwyer, N. P. Lockyer, J. Miyan, P. Gardner, C. Hart, M. Brown and N. W. Clarke, Biopolymers, 2005, 77, 18.

56 M. M. Mariani, P. Lampen, J. Popp, B. R. Wood and V. Deckert, Analyst, 2009, 134, 1154.

57 A. D. Meade, C. Clarke, F. Draux, G. D. Sockalingum, M. Manfait, F. M. Lyng and H. J. Byrne, Anal. Bioanal. Chem., 2010, 396, 1781.

58 F. Draux, C. Gobinet, J. Sule-Suso, A. Trussardi, M. Manfait, P. Jeannesson and G. D. Sockalingum, Anal. Bioanal. Chem., 2010, 397, 2727.

59 I. Notingher, S. Verrier, S. Haque, J. M. Polak and L. L. Hench, Biopolymers, 2003, 72, 230.

60 J. De Gelder, K. De Gussem, P. Vandenabeele and L. Moens, J. Raman Spectrosc., 2007, 38, 1133.

61 S. Verrier, A. Zoladek and I. Notingher, Methods Mol. Biol., 2011, 740, 179.

62 H. Nawaz, F. Bonnier, P. Knief, O. Howe, F. M. Lyng, A. D. Meade and H. J. Byrne, Analyst, 2010, 135, 3070.

63 H. Nawaz, F. Bonnier, A. D. Meade, F. M. Lyng and H. J. Byrne, Analyst, 2011, 136, 2450.

64 O. Vrana, V. Masek, V. Drazan and V. Brabec, J. Struct. Biol., 2007, 159, 1.

65 J. M. Benevides and G. J. Thomas, Nucleic Acids Res., 1983, 11, 5747.

66 A. Z. Fernandis and M. R. Wenk, J. Chromatogr. B: Anal. Technol. Biomed. Life Sci., 2009, 877, 2830.

67 C. Nieva, M. Marro, N. Santana-Codina, S. Rao, D. Petrov and A. Sierra, PLoS One, 2012, 7, e46456. 